\title{
Oxidative stress-induced chromosome breaks within the $A B L$ gene: a model for chromosome rearrangement in nasopharyngeal carcinoma
}

\author{
Sang-Nee $\operatorname{Tan}^{1}$, Sai-Peng $\operatorname{Sim}^{1 *}$ and Alan Soo-Beng Khoo ${ }^{2}$
}

\begin{abstract}
Background: The mechanism underlying chromosome rearrangement in nasopharyngeal carcinoma (NPC) remains elusive. It is known that most of the aetiological factors of NPC trigger oxidative stress. Oxidative stress is a potent apoptotic inducer. During apoptosis, chromatin cleavage and DNA fragmentation occur. However, cells may undergo DNA repair and survive apoptosis. Non-homologous end joining (NHEJ) pathway has been known as the primary DNA repair system in human cells. The NHEJ process may repair DNA ends without any homology, although region of microhomology (a few nucleotides) is usually utilised by this DNA repair system. Cells that evade apoptosis via erroneous DNA repair may carry chromosomal aberration. Apoptotic nuclease was found to be associated with nuclear matrix during apoptosis. Matrix association region/scaffold attachment region (MAR/SAR) is the binding site of the chromosomal DNA loop structure to the nuclear matrix. When apoptotic nuclease is associated with nuclear matrix during apoptosis, it potentially cleaves at MAR/SAR. Cells that survive apoptosis via compromised DNA repair may carry chromosome rearrangement contributing to NPC tumourigenesis. The Abelson murine leukaemia (ABL) gene at 9q34 was targeted in this study as 9q34 is a common region of loss in NPC. This study aimed to identify the chromosome breakages and/or rearrangements in the $A B L$ gene in cells undergoing oxidative stress-induced apoptosis.

Results: In the present study, in silico prediction of MAR/SAR was performed in the ABL gene. More than $80 \%$ of the predicted MAR/SAR sites are closely associated with previously reported patient breakpoint cluster regions (BCR). By using inverse polymerase chain reaction (IPCR), we demonstrated that hydrogen peroxide $\left(\mathrm{H}_{2} \mathrm{O}_{2}\right)$-induced apoptosis in normal nasopharyngeal epithelial and NPC cells led to chromosomal breakages within the ABL BCR that contains a MAR/SAR. Intriguingly, we detected two translocations in $\mathrm{H}_{2} \mathrm{O}_{2}$-treated cells. Region of microhomology was found at the translocation junctions. This observation is consistent with the operation of microhomology-mediated NHEJ.

Conclusions: Our findings suggested that oxidative stress-induced apoptosis may participate in chromosome rearrangements of NPC. A revised model for oxidative stress-induced apoptosis mediating chromosome rearrangement in NPC is proposed.
\end{abstract}

Keywords: NPC, Oxidative stress, $\mathrm{H}_{2} \mathrm{O}_{2}$, Apoptosis, $A B L$, MAR/SAR

\footnotetext{
* Correspondence: spsim@unimas.my

${ }^{1}$ Department of Paraclinical Sciences, Faculty of Medicine and Health

Sciences, Universiti Malaysia Sarawak, Sarawak, Malaysia

Full list of author information is available at the end of the article
}

(c) The Author(s). 2018 Open Access This article is distributed under the terms of the Creative Commons Attribution 4.0 International License (http://creativecommons.org/licenses/by/4.0/), which permits unrestricted use, distribution, and reproduction in any medium, provided you give appropriate credit to the original author(s) and the source, provide a link to the Creative Commons license, and indicate if changes were made. The Creative Commons Public Domain Dedication waiver (http://creativecommons.org/publicdomain/zero/1.0/) applies to the data made available in this article, unless otherwise stated. 


\section{Background}

Nasopharyngeal carcinoma (NPC) is a malignant neoplasm derived from mucosal epithelium of the nasopharynx. According to the World Health Organization (WHO), NPC can be classified into three subtypes according to the degree of epithelial differentiation, namely keratinising squamous cell carcinoma (Type I), non-keratinising squamous cell carcinoma (Type II) and undifferentiated or poorly differentiated carcinoma (Type III) [1].

NPC is a rare malignancy in most parts of the world; the incidence rates are below one per 100,000 persons per year $[2,3]$. However, there are a few well-known notable exceptions [3]. The intermediate rates were reported in South-Eastern Asia, Northern Africa, the Middle East and Arctic Region [3, 4]. The highest incidence rate was observed among Southern Chinese living in central Guangdong province. The annual incidence rates for males and females in central Guangdong province are 23.3 per 100,000 and 8.9 per 100,000 , respectively [4]. The NPC incidence rates are generally increasing from Northern China to Southern China [3, 4]. In addition, an exceptionally high incidence rate has been reported among the Bidayuh people, the second biggest ethnic group in Sarawak, Malaysia. The age-adjusted rate of Sarawak residents is 13.5 per 100,000 and 6.2 per 100,000 in males and females, respectively. Although the average rate in Sarawak is intermediate, the incidence rate for Bidayuh people is about 50\% higher than that in Hong Kong (a part of the Cantonese region of Guangdong province) [5].

NPC is strongly associated with Epstein-Barr Virus (EBV) infection [6-8] as well as dietary [9-11], environmental $[12]$ and genetic factors $[13,14]$. Several genetic aberrations have been reported to be related to the development of NPC, suggesting that NPC tumourigenesis involves multiple genetic changes. These include chromosomal gains or losses [15-19], loss of heterozygosity (LOH) [20-23], homozygous deletions [24-27], promoter hypermethylation of tumour suppressor genes [28-31] and shortening of chromosome telomeres [32, 33].

Although the consistent chromosome rearrangements have long been identified in NPC, the molecular mechanism underlying the chromosome rearrangements of NPC remains poorly understood. In addition to EBV infection, long-term exposures to nitrosamines, formaldehyde, cigarette smoke and wood dust have all been found to be associated with NPC [12, 34-36]. More recently, much concern has been raised about the association between chronic inflammation of sinonasal tract and NPC [37, 38]. It is remarkable that all these aetiological factors may trigger oxidative stress [39-43]. Oxidative stress is an imbalance of pro-oxidants and antioxidants resulting in a disruption of redox signalling and control. Pro-oxidants induce oxidative stress either through excessive production of reactive oxygen species
(ROS) or inhibition of antioxidant systems [44]. ROS are chemically-reactive molecules containing oxygen which include peroxyl RO, hydroxyl radical $\mathrm{OH}$., superoxide $\mathrm{O}^{2}$.- and hydrogen peroxide $\mathrm{H}_{2} \mathrm{O}_{2}$ [45]. ROS cause several kinds of DNA damages, including strand cleavage, base modification and DNA-protein cross-linkage [45, 46]. Importantly, formaldehyde and acrolein, a component of cigarette smoke, are reactive aldehydes. In addition, reactive aldehydes may also be produced endogenously during oxidative stress. Aldehydes may cause adduct formation that impairs the function of DNA, RNA and proteins via electrophile-nucleophile interaction. Exposure to environmental aldehydes has been shown to be associated with the onset and development of human diseases that involve oxidative stress. It has been suggested that environmental and endogenous aldehydes may interact additively and exacerbate the cellular oxidative damage [47].

An evaluation of the levels of 8-hydroxy-2'-deoxyguanosine (8-OHdG), a biomarker of oxidative DNA damage, had been done among NPC patients. The tissue and serum levels of $8-\mathrm{OHdG}$ in NPC patients have been found to be significantly higher than those in control patients [48]. Oxidative stress was suggested to play an important role in carcinogenesis [49]. Since there is a strong link between the aetiological factors of NPC and oxidative stress, it is intriguing to investigate the role of oxidative stress in the molecular mechanisms underlying chromosome rearrangements of NPC.

Oxidative stress may induce apoptosis $[50,51] . \mathrm{H}_{2} \mathrm{O}_{2}$ has been well known as an apoptotic inducer for various human cell types, including osteoblasts [52, 53], sarcoma cells [54], osteosarcoma cells [55], hepatoma cells [56], astrocytoma cells [57], Jurkat T lymphocytes [58] and Fanconi's anaemia cells [59]. Apoptosis or programmed cell death was first described by Kerr et al. (1972). Apoptosis is a type of genetically controlled cell suicide which occurs naturally in multicellular organisms in order to eliminate poisonous cells. Apoptosis is morphologically characterised by condensation of chromatin, fragmentation of nuclei, compaction of cytoplasmic organelles, cell shrinkage and cytoplasmic membrane blebbing [60-62]. Apoptosis is related to several biochemical events, including externalisation of phosphatidylserine (PS) on cell membrane, alteration in mitochondrial membrane potential (MMP), release of cytochrome $c$ (cyt $c$ ) from mitochondria, caspase activation and internucleosomal cleavage of DNA [63].

The alteration of nuclear chromatin during apoptosis is often associated with fragmentation of the genomic DNA into high-molecular-weight (HMW) DNA of 30 to 50 and 200 to $300 \mathrm{kbp}[64,65]$. These sizes of fragments have been suggested to be derived from the release of loops $(50 \mathrm{kbp})$ or rosettes $(300 \mathrm{kbp}$ ) of chromatin, probably when they become detached from their binding 
sites on the nuclear scaffold [66]. Further degradation of the HMW DNA produces the internucleosomal DNA fragments of 180 to $200 \mathrm{bp}[67,68]$.

Cells undergoing apoptosis may recover from the execution phase of apoptosis upon DNA repair [69, 70]. There are two major double-strand breaks (DSBs) repair pathways, namely homologous recombination (HR) and non-homologous end joining (NHEJ) [71, 72]. Chromosomal DSB repair by $H R$ is predominant during late $S$ / G2 phases of the cell cycle. NHEJ is the more frequently used pathway that can repair a DSB at any time during the cell cycle. These two pathways have different degree of requirement for DNA homology. The HR pathway requires sufficient homology, usually more than $100 \mathrm{bp}$. Given that the HR DNA repair system ligates two DNA ends with homologous sequences, it gives rise to precise DNA repair. The NHEJ DNA repair system joins two DNA ends without intensive requirement of sequence homology. This pathway joins two DNA terminals with microhomology of a few base pairs [71, 73, 74]. NHEJ pathway has been shown to be prone to cause erroneous repair of DSBs. This may in turn lead to chromosomal aberrations [75]. It has been suggested that interaction of the NHEJ DNA repair system with apoptosis can act as a mechanism leading to translocation in leukaemia [70].

Chromosomal breakage takes place in the initial stage of chromosome rearrangement and apoptotic DNA fragmentation. It has been observed that chromosome breaks do not randomly occur throughout a gene. Rather, chromosome breaks normally fall within certain regions that contain specific chromatin structures, such as matrix association region/scaffold attachment region (MAR/SAR) [76, 77]. MAR/SAR are DNA sequences where DNA loop structure attaches to nuclear scaffold/ matrix proteins [78]. There are two breakpoint cluster regions (BCR) identified in the $A F 9$ gene. These two BCRs are bordered by two experimentally isolated MAR/SARs [76]. The BCR of the mixed lineage leukaemia $(M L L)$ gene has also been found to contain two MAR/SAR sequences [78]. In addition, the most crucial apoptotic nuclease CAD has been reported to associate with the nuclear matrix of apoptotic cells [79].

We previously demonstrated that in normal nasopharyngeal epithelial and NPC cells, oxidative stress-induced apoptosis resulted in chromosome breaks in the AF9 gene located on chromosome 9p22. We further demonstrated that caspase-activated DNase (CAD) may be a major player in mediating the oxidative stress-induced chromosomal cleavages. A few chromosome breaks were identified within the $A F 9$ region that was previously reported to participate in translocation in an acute lymphoblastic leukaemia (ALL) patient. These findings suggested that oxidative stress-induced apoptosis may play an important role in mediating chromosome rearrangements in NPC
[80]. In the present study, we further investigated the potential role of oxidative stress-induced apoptosis by targeting the Abelson murine leukaemia viral oncogene homologue $1(A B L)$ gene located on chromosome 9q34. This study targeted the $A B L$ gene because $9 \mathrm{q} 34$ is a common region of loss in NPC [23].

The $A B L$ gene is a proto-oncogene which encodes a $150 \mathrm{kDa}$ nonreceptor protein tyrosine kinase. It was first recognised as the cellular homologue of the $v$ - $a b l$ oncogene product of the Abelson murine leukaemia virus $[81,82]$. The ABL protein has a complex structure that contains many domains. These domains are found in proteins which are involved in the formation of complexes in signal transduction pathway. It has been demonstrated that overexpression of $A B L$ in fibroblast resulted in growth arrest [83]. The product of $A B L-B C R$ fusion appears to be an abnormal kinase that stimulates the proliferation of myeloid cells leading to chronic myelogenous leukaemia (CML) [84]. The $A B L$ gene is 173,795 bp in length and it consists of 11 exons [Ensembl:ENSG00000097007]. The description of exons and introns in the $A B L$ gene is shown in Additional file 1.

By using MAR/SAR recognition signature (MRS), we predicted 12 possible MAR/SAR sites in the $A B L$ gene. We demonstrated that oxidative stress-induced apoptosis resulted in chromosome breaks in the $A B L \mathrm{BCR}$ which contains a MAR/SAR site. We detected shift translocations in $\mathrm{H}_{2} \mathrm{O}_{2}$-treated normal nasopharyngeal epithelial cells. Interestingly, we found region of microhomology at the breakpoint junctions. This observation suggests a role for NHEJ DNA repair system in mediating the translocation. At last, we illustrated the possible role of oxidative stress-induced apoptosis in mediating chromosome rearrangements in NPC via NHEJ DNA repair system.

\section{Results}

In silico prediction of MAR/SAR by using MAR/SAR recognition signature (MRS)

Potential MAR/SAR sites in the $A B L$ gene were predicted by using MRS. MRS is a bipartite sequence that is strongly associated with MAR/SAR [85]. This bipartite sequence consists of $16 \mathrm{bp}$ nucleotide motif (AWWRTAANNWWGNNNC) within a distance of $200 \mathrm{bp}$ of the 8 bp nucleotide motif (AATAAYAA). However, for our preliminary results in the $A B L$ gene, we only found one MRS (MAR/SAR 9 in Table 1) in the biochemically identified SAR1 [77]. The distance between the 8 bp sequence element and the $16 \mathrm{bp}$ sequence element was $248 \mathrm{bp}$. Therefore, in this study, we set the maximal distance between the two sequence elements at $250 \mathrm{bp}$.

By using MRS, we predicted 12 potential MAR/SAR sites in the $A B L$ gene. The nucleotide positions of the MRSs with their sequence composition, relative orientation, distance 
Table 1 MAR/SAR predicted in the ABL gene

\begin{tabular}{|c|c|c|c|c|c|c|}
\hline Predicted MAR/SAR & AWWRTAANNWWGNNNC (16 bp) & Nucleotide position & AATAAYAA (8 bp) & Nucleotide position & Distance (bp) & Location in exon/intron \\
\hline $1-1$ & ATTGTAACCATATCTC (C) & $26,055-26,070$ & AATAATAA (C) & $26,118-26,125$ & +47 & Intron 1 \\
\hline $1-2$ & ATCATAACTTAGCAAC (C) & $26,613-26,628$ & AATAACAA (W) & $26,565-26,572$ & -40 & Intron 1 \\
\hline 2 & AAAAAAATTTTGTACC (C) & $29,601-29,616$ & AATAATAA (C) & $29,629-29,636$ & +12 & Intron 1 \\
\hline \multirow[t]{2}{*}{$3-1$} & ATAATAATTATACAAC (C) & $80,698-80,713$ & AATAATAA (W) & $80,726-80,733$ & +12 & Intron 1 \\
\hline & AATATAAATAAAGTGC (W) & $80,732-80,747$ & & & Overlap & \\
\hline $3-2$ & ATTGTAACTAAGGTTC (C) & $81,458-81,473$ & AATAACAA (C) & $81,422-81,429$ & -28 & Intron 1 \\
\hline \multirow[t]{2}{*}{4} & ATAATAATAAAGAGAT (W) & $99,259-99,274$ & AATAATAA (W) & $99,261-99,268$ & Overlap & Intron 1 \\
\hline & AATATAATCAACTGAC (W) & $99,447-99,462$ & & & -178 & \\
\hline 5 & ATAAAAAGGAAGATTC (W) & $105,498-105,513$ & AATAATAA (C) & $105,616-105,623$ & +102 & Intron 1 \\
\hline \multirow[t]{3}{*}{6} & AAAAAAAAAAAGACTC (C) & $108,315-108,330$ & AATAATAA (C) & $108,484-108,491$ & +153 & Intron 1 \\
\hline & & & AATAATAA (C) & $108,487-108,494$ & +156 & \\
\hline & & & AATAATAA (C) & $108,490-108,497$ & +159 & \\
\hline 7 & AATGTAACAGAGAGCC (C) & $117,122-117,137$ & AATAACAA (W) & $117,343-117,350$ & +205 & Intron 1 \\
\hline 8 & AAAATAAACATATACC (W) & $119,757-119,772$ & AATAATAA (W) & $119,739-119,746$ & -10 & Intron 1 \\
\hline 9 & AAAGTAAAATTGAAAG (C) & $133,546-133,561$ & AATAACAA (W) & $133,810-133,817$ & +248 & Intron 1 \\
\hline 10 & ATTACAAGTTTGGTAC (C) & $144,212-144,227$ & AATAATAA (C) & $143,996-144,003$ & -208 & Intron 3 \\
\hline 11 & ATAAAAACAAAGAAGC (C) & $163,018-163,033$ & AATAACAA (W) & $163,048-163,055$ & +14 & Intron 7 \\
\hline 12 & AAAATAATAATGGCCA (W) & $167,856-167,871$ & AATAATAA (W) & $167,858-167,865$ & Overlap & Intron 10 \\
\hline
\end{tabular}

Nucleotide positions of the MRSs with their sequence composition, relative orientation (C, Crick strand and W, Watson strand), distance between the two sequence elements and location of the MRSs in the exon or intron of the $A B L$ gene are shown. A negative distance indicates that 8 bp sequence element precedes the $16 \mathrm{bp}$ sequence element

between the two sequence elements and location of the MRSs in the exon or intron of the $A B L$ gene are shown in Table 1 . Out of the 12 predicted MAR/SAR sites, 9 were identified in intron 1 which is the largest intron (approximately $140 \mathrm{~kb}$ in length) in the $A B L$ gene (approximately $175 \mathrm{~kb}$ in length) (MAR/SAR 1-9 in Table 1). One potential MAR/SAR site was separately found in intron 3 (MAR/SAR 10 in Table 1) and intron 10 (MAR/SAR 11 in Table 1). The distribution of the predicted MAR/SAR sites in the $A B L$ gene is shown in Fig. 1. One MAR/SAR site (MAR/SAR 9 in Table 1) was predicted within the biochemically defined SAR1 which is located in the second intron 1 [77].

\section{Apoptosis detection}

NP69 cells were either left untreated or treated with $100 \mu \mathrm{M}$ of $\mathrm{H}_{2} \mathrm{O}_{2}$ for 16 and $24 \mathrm{~h}$ while $\mathrm{HK} 1$ cells were either left untreated or treated with $50 \mu \mathrm{M}$ for 4 and $8 \mathrm{~h}$. Cells treated with CPT was included as a positive control. The cells were then subjected to flow cytometric analyses of PS externalisation and MMP loss.

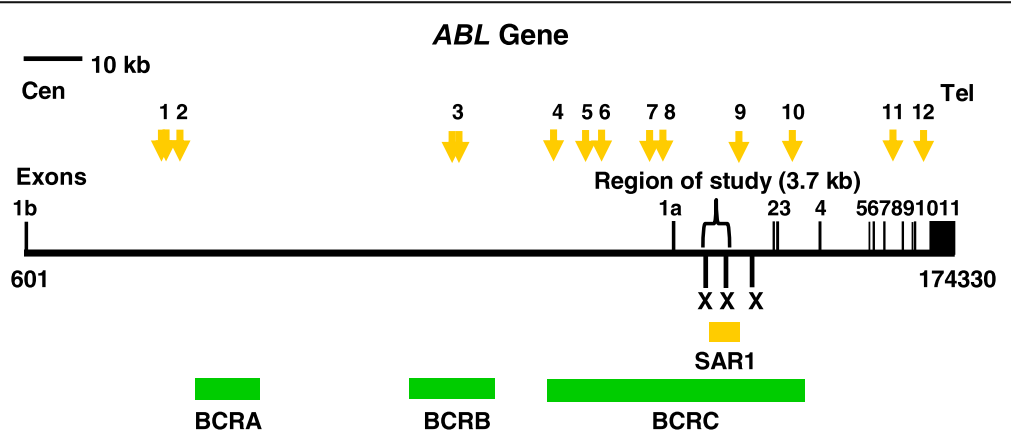

Fig. 1 Distribution of potential MAR/SAR sites predicted in the ABL gene. The ABL genomic map from nucleotide positions 601-174330 is illustrated above [Ensembl:ENSG00000097007]. The locations of exons 1 to 11 are shown. Green boxes represent the three previously reported patient breakpoints cluster regions which are designated as BCRA, BCRB and BCRC. Yellow box shows the previously biochemically extracted MAR/SAR which is designated as SAR1 [77]. Yellow arrows represent the potential MAR/SARs predicted by MRS. Clusters of more than one MRS within close proximity are regarded as a single potential MAR/SAR site. For instance, there were two MRSs predicted in BCRB, however, they were regarded as a single potential MAR/SAR site (MAR/SAR 3) because they were found in close proximity. There was one MAR/SAR site (MAR/SAR 9) predicted in the experimentally isolated SAR1 


\section{Phosphatidylserine (PS) externalisation}

As shown in Fig. 2a i, the percentages of apoptotic cells detected in NP69 treated with $100 \mu \mathrm{M}$ of $\mathrm{H}_{2} \mathrm{O}_{2}$ for 16 and $24 \mathrm{~h}$ were 2.82 -fold $(p=0.000170)$ and 2.87 -fold $(p=3.4346 \mathrm{E}-8)$ higher than that detected in the untreated control, respectively. The percentages of apoptotic cells detected in $\mathrm{HK} 1$ treated with $50 \mu \mathrm{M}$ of $\mathrm{H}_{2} \mathrm{O}_{2}$ for 4 and $8 \mathrm{~h}$ were 1.48 -fold $(p=0.005735)$ and 1.92 -fold $(p=0.000477)$ higher than that detected in the untreated control, respectively (Fig. 2b i). Figure 2a $\mathrm{i}$ and $\mathrm{b}$ ii are the representative dot plot diagrams showing the apoptotic population of $\mathrm{H}_{2} \mathrm{O}_{2}$-treated NP69 and HK1 cells, respectively.

\section{Mitochondrial membrane potential (MMP) loss}

As shown in Fig. 3a i, the percentages of apoptotic cells detected in NP69 treated with $100 \mu \mathrm{M}$ of $\mathrm{H}_{2} \mathrm{O}_{2}$ for 16 and $24 \mathrm{~h}$ were 2.45 -fold $(p=0.006)$ and 2.25 -fold $(p=0.002)$ higher than that detected in the untreated control, respectively. The percentages of apoptotic cells detected in
HK1 treated with $50 \mu \mathrm{M}$ of $\mathrm{H}_{2} \mathrm{O}_{2}$ for 4 and $8 \mathrm{~h}$ were 1.68 -fold $(p=0.009)$ and 2.18-fold $(p=0.007)$ higher than that detected in the untreated control, respectively (Fig. 3b i). Figure $3 \mathrm{a}$ ii and $\mathrm{b}$ ii are the representative contour plot diagrams showing the apoptotic population of $\mathrm{H}_{2} \mathrm{O}_{2}$-treated NP69 and HK1 cells, respectively.

\section{IPCR detection of chromosome breaks within the $A B L$ gene mediated by stress-induced apoptosis}

NP69 cells at confluency of $30-40 \%$ were treated with 10,50 and $100 \mu \mathrm{M}$ of $\mathrm{H}_{2} \mathrm{O}_{2}$ for 16 and $24 \mathrm{~h}$ while HK1 cells at optimal density were treated with 1,10 or $50 \mu \mathrm{M}$ of $\mathrm{H}_{2} \mathrm{O}_{2}$ for 2, 4, 6 and $8 \mathrm{~h}$. For each cell line, an untreated sample was included to serve as a cell control. Nested IPCR was employed to identify chromosome breaks mediated by stress-induced apoptosis. The IPCR bands representing the $A B L$ cleaved fragments detected were isolated, purified and sequenced.

Figures 4 and 5 show the IPCR results for $\mathrm{H}_{2} \mathrm{O}_{2}$-treated NP69 and HK1 cells, respectively. In the manipulation for a i

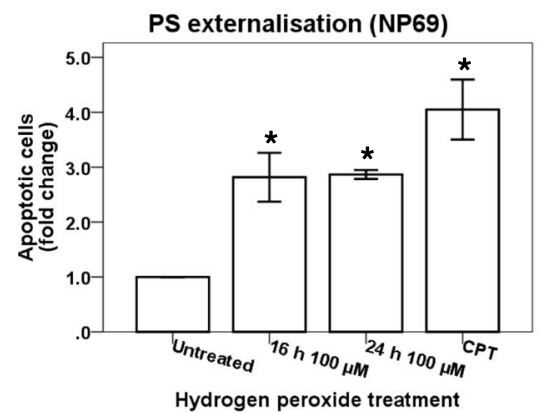

a ii

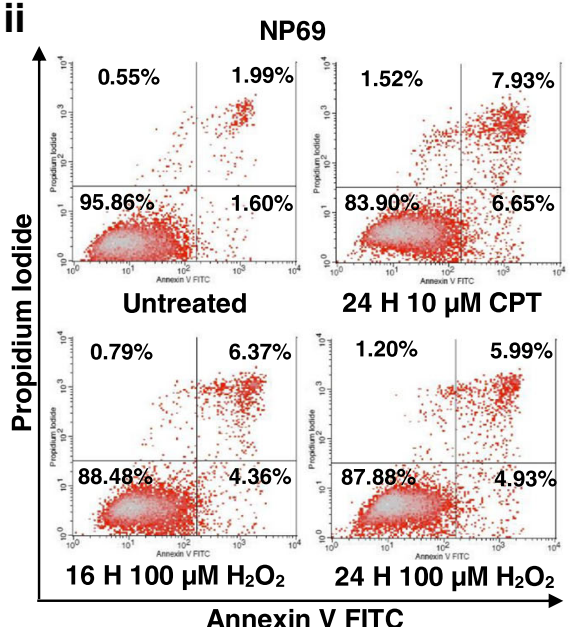

b i

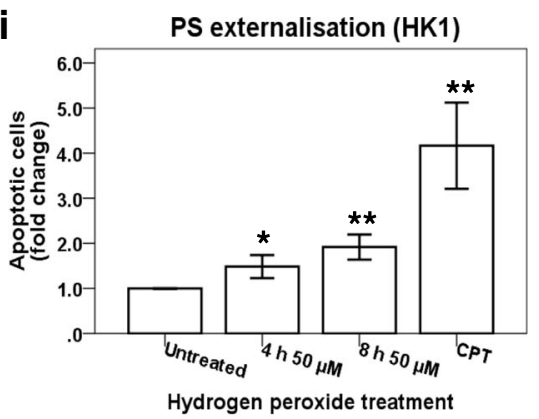

b ii

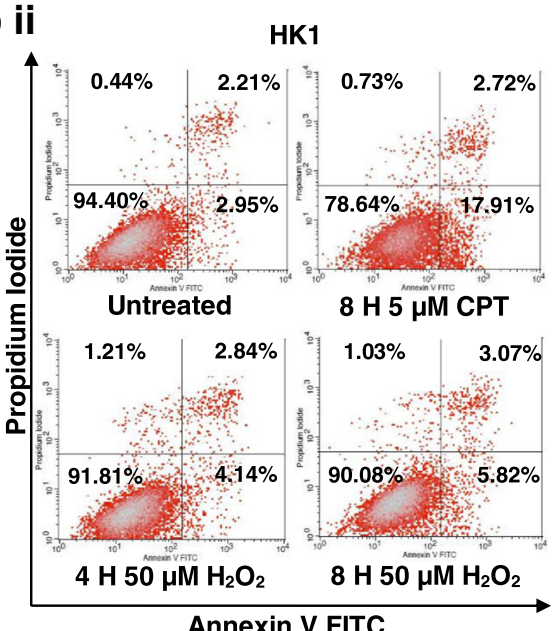

Fig. 2 Flow cytometric analysis of phosphatidylserine (PS) externalisation. NP69 cells were either left untreated or treated with $100 \mu \mathrm{M}$ of $\mathrm{H}_{2} \mathrm{O}_{2}$ for 16 and $24 \mathrm{~h}$ while HK1 cells were either left untreated or treated with $50 \mu \mathrm{M}$ for 4 and 8 h. Cells treated with CPT was included as a positive control. The percentage of cells showing PS externalisation was determined in $\mathrm{H}_{2} \mathrm{O}_{2}$-treated NP69 cells (a i) and HK1 cells (b i). Means and SD of three independent experiments performed in duplicate are shown. Data are expressed as fold change normalised to untreated control. ${ }^{*} p<0.01$, ${ }^{*} p<0.001$ (Student's $t$ test). The representative dot plot diagrams indicating the apoptotic populations of (a ii) $\mathrm{H}_{2} \mathrm{O}_{2}$-treated $\mathrm{NP} 69$ cells and (b ii) $\mathrm{H}_{2} \mathrm{O}_{2}$-treated HK1 cells are shown. The lower left quadrants indicate healthy cells; the lower right quadrants indicate cells in early apoptosis; the upper right quadrants indicate cells in late apoptosis and necrosis 
a $\mathbf{i}$

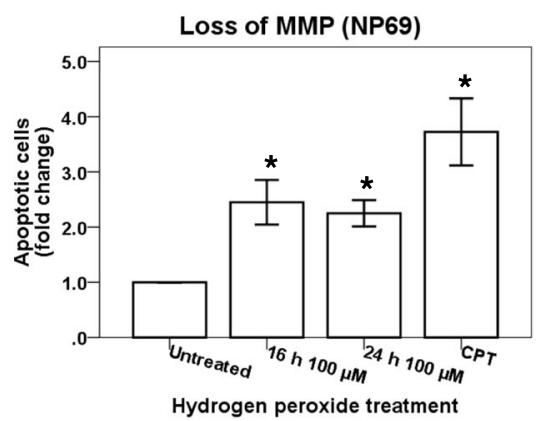

a ii

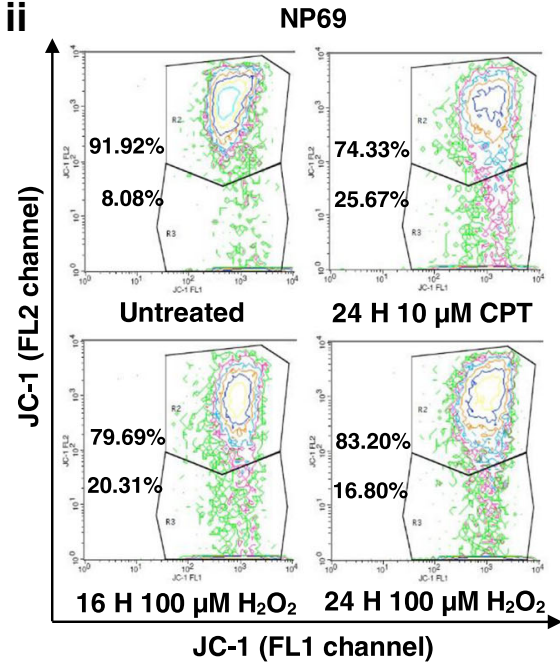

b i

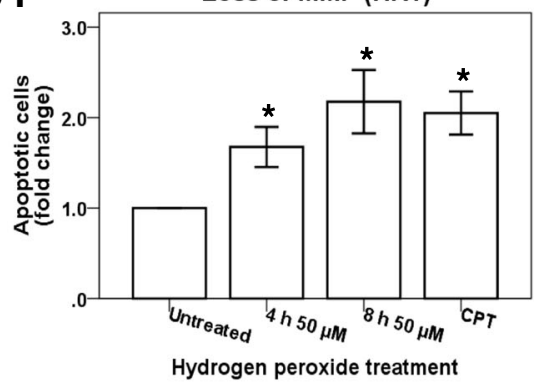

b ii

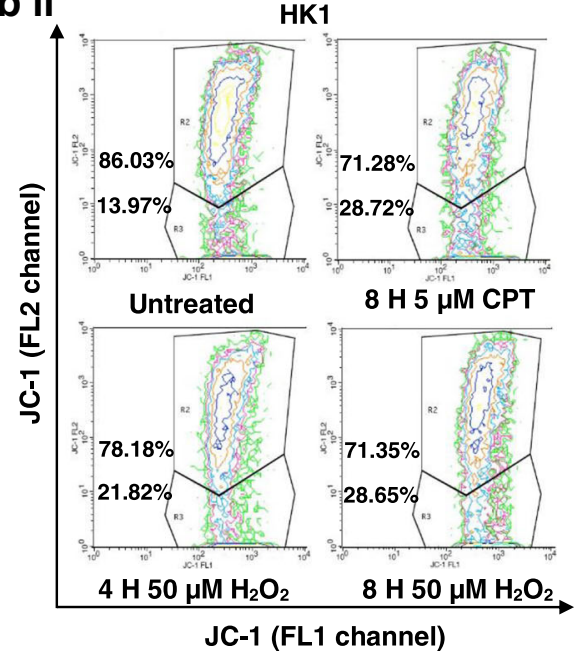

Fig. 3 Flow cytometric analysis of mitochondrial membrane potential (MMP) loss. NP69 cells were either left untreated or treated with $100 \mu \mathrm{M}$ of $\mathrm{H}_{2} \mathrm{O}_{2}$ for 16 and $24 \mathrm{~h}$ while HK1 cells were either left untreated or treated with $50 \mu \mathrm{M}$ for 4 and 8 h. Cells treated with CPT was included as a positive control. The percentage of cells showing MMP loss was determined in $\mathrm{H}_{2} \mathrm{O}_{2}$-treated NP69 cells (a i) and HK1 cells (b i). Means and SD of two independent experiments performed in duplicate are shown. Data are expressed as fold change normalised to untreated control. ${ }^{*} p<0.01$ (Student's $t$ test). The representative contour plot diagrams indicating the apoptotic populations of $\left(\mathbf{a}\right.$ ii) $\mathrm{H}_{2} \mathrm{O}_{2}$-treated $\mathrm{NP}_{6} 9$ cells and (b ii) $\mathrm{H}_{2} \mathrm{O}_{2}-$ treated HK1 cells are shown. The upper quadrants indicate healthy cells whereas the lower quadrants indicate cells expressing MMP loss

nested IPCR, Age I (RE2 in Fig. 12) was used to linearise the cyclised DNA. If there is no breakage within the $A B L$ gene, the IPCR product will be approximately $3 \mathrm{~kb}$. On the contrary, if there is any breakage within the $A B L$ gene, it should produce IPCR products which are smaller than $3 \mathrm{~kb}$. As shown in Figures $4 \mathrm{a}$ and $5 \mathrm{a}$, the $A B L$ intact fragment of $3 \mathrm{~kb}$ is present in all of the samples. This amplification could serve as an internal control by proposing an optimal IPCR condition for the $A B L$ gene. Besides, numerous IPCR bands of less than $3 \mathrm{~kb}$ were also obtained. However, these bands are less intense as compared with the intact fragment. This could be due to the competition between the intact fragments and the cleaved fragments for the amplification process. The intact fragments are usually more abundant as compared with the cleaved fragments. Consequently, the amplification of the cleaved fragments would be less efficient in the presence of the intact fragments. Therefore, double digestion with Age I and BsaA I or Age I and EcoR I (RE3 in Fig. 12) was used to eliminate competition from the intact fragments for the nested IPCR reaction. These two different digestions gave rise to the detection of chromosome breaks within different regions. With double digestion of Age I and EcoR I, numerous distinct IPCR bands of less than $3 \mathrm{~kb}$ which represent the cleaved $A B L$ fragment were detected in $\mathrm{H}_{2} \mathrm{O}_{2}$-treated NP69 (Fig. 4b, lanes 4-9) and $\mathrm{H}_{2} \mathrm{O}_{2}$-treated HK1 (Fig. 5b, lanes 4, 7, 9, 10, 11, 12 and 13) cells. A few cleavage bands were detected in the untreated NP69 cells (Fig. 4b, lane 1) which might be due to endogenous DNA breaks in the minority of untreated cells which were unhealthy. However, in general, there were more cleaved fragments detected in the treated samples compared with the untreated sample.

As shown in Fig. 4c, the intact fragment of $3 \mathrm{~kb}$ was still detected upon double digestion with Age I and BsaA I. Most probably, this was due to incomplete digestion by Age I and BsaA I. Regardless of the incomplete digestion, several cleavage bands of different sizes were detected in NP69 cells treated with various concentrations of $\mathrm{H}_{2} \mathrm{O}_{2}$ for different time points (Fig. 4c, lanes 4-9). 


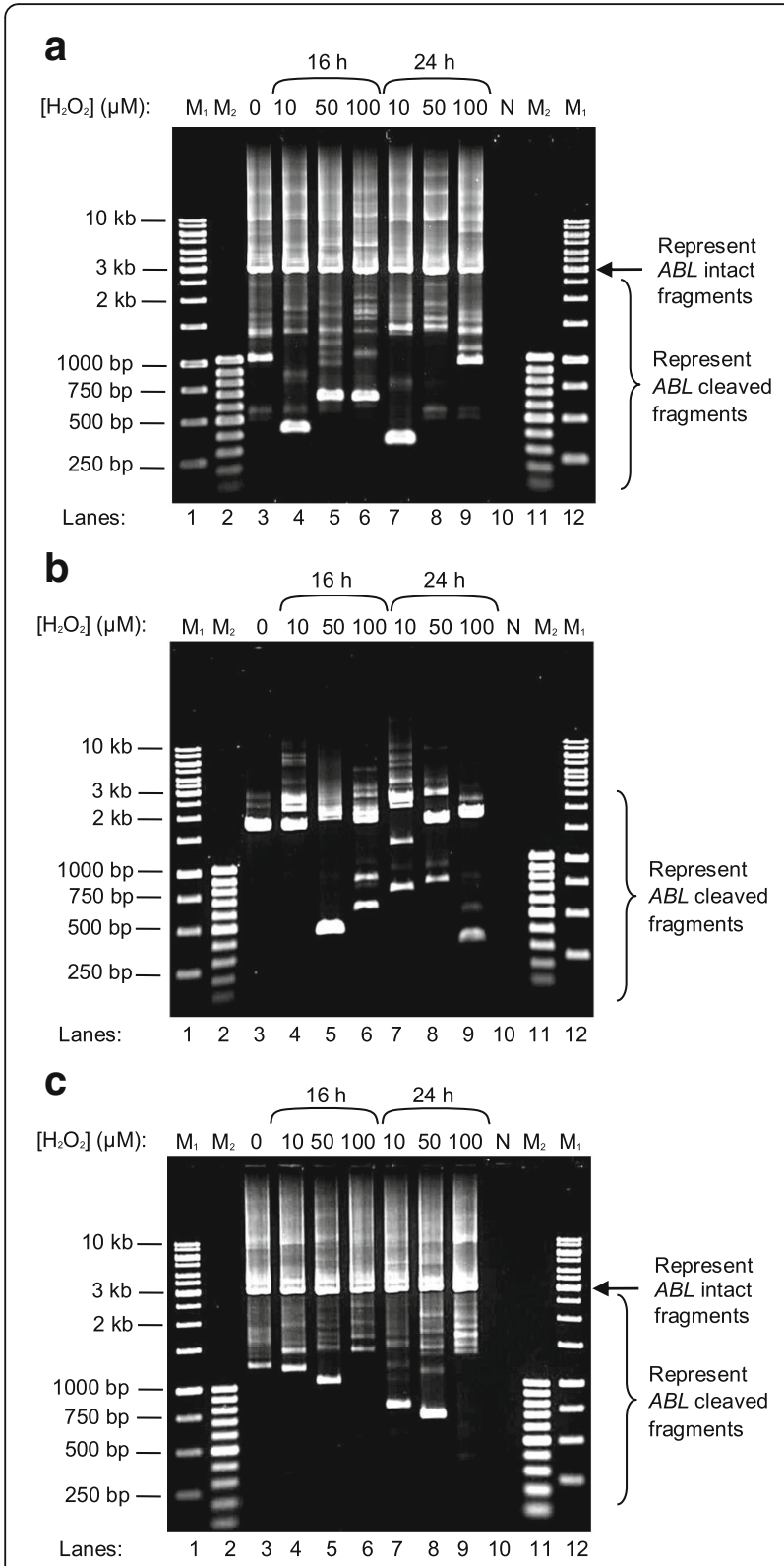

Fig. 4 Nested IPCR detection of DNA breakages within the $A B L$ gene in $\mathrm{H}_{2} \mathrm{O}_{2}$-treated NP69. NP69 cells at 30-40\% confluency were either untreated (lane 3) or treated with $10 \mu \mathrm{M}$ (lanes 4 and 7), $50 \mu \mathrm{M}$ (lanes 5 and 8) or $100 \mu \mathrm{M}$ (lanes 6 and 9) of $\mathrm{H}_{2} \mathrm{O}_{2}$ for $16 \mathrm{~h}$ (lanes 4-6) and $24 \mathrm{~h}$ (lanes 7-9). Genomic DNA was isolated and manipulated for nested IPCR. In the manipulation for nested IPCR, the DNA samples were subjected to digestion with Age I (a), double digestion with Age I and ECOR I (b) or double digestion with Age I and BsaA I (c). The IPCR products were analysed on $1 \%$ agarose gel. Side arrows in panels a and $\mathbf{c}$ indicate the position of the $3 \mathrm{~kb}$ IPCR bands resulting from the amplification of the intact $A B L$ gene. Side brackets in panels $\mathbf{a}, \mathbf{b}$ and $\mathbf{c}$ indicate the possible IPCR bands from the $A B L$ cleaved fragments. Negative control for PCR was included (lane 10). This IPCR result is representative of 2 repeats with similar results. $M_{1}: 1 \mathrm{~kb}$ DNA ladder. $\mathrm{M}_{2}: 100 \mathrm{bp}$ DNA ladder
DNA breakages were detected in cell samples treated with various concentrations of $\mathrm{H}_{2} \mathrm{O}_{2}$ at various time points. Based on the microscopic analysis and flow cytometric analyses, the optimal concentration and time point were determined. These optimal concentration and time point were used to repeat the experiments in NP69 and HK1 cells. For NP69 cells, we selected concentration of $100 \mu \mathrm{M}$ with exposure time of 16 and $24 \mathrm{~h}$. The microscopic analysis on $\mathrm{H}_{2} \mathrm{O}_{2}$-treated NP69 cells showed that cytoplasmic shrinkage was only observed in cells treated with $100 \mu \mathrm{M}$ for 16 and $24 \mathrm{~h}$ (Additional file 2). In addition, we performed flow cytometric analyses of PS externalisation and MMP loss on NP69 cells treated with $100 \mu \mathrm{M}$ for 16 and 24 h. In these two flow cytometric assays, both samples showed significantly higher percentage of apoptosis as compared with that of the untreated control (Figs. 2a i and 3a i).

For HK1 cells, we chose concentration of $50 \mu \mathrm{M}$ with exposure time of $8 \mathrm{~h}$. Cell blebbing, which is one of the major morphological changes, was relatively more prominent in $\mathrm{HK} 1$ cells treated with $50 \mu \mathrm{M}$ of $\mathrm{H}_{2} \mathrm{O}_{2}$ for $8 \mathrm{~h}$ compared with those treated with lower concentration ( 1 and $10 \mu \mathrm{M})$ and shorter exposure time (2, 4 and $6 \mathrm{~h}$ ) (Additional file 3). Moreover, the flow cytometric analysis of PS externalisation on sample treated with $50 \mu \mathrm{M}$ of $\mathrm{H}_{2} \mathrm{O}_{2}$ for $8 \mathrm{~h}$ showed a more promising result compared with the sample treated with $50 \mu \mathrm{M}$ of $\mathrm{H}_{2} \mathrm{O}_{2}$ for $4 \mathrm{~h}$ (Fig. 2b i).

$\mathrm{H}_{2} \mathrm{O}_{2}$ treatment was thus repeated in NP69 and HK1 cells with the selected concentration and time point. NP69 cells at confluency of $30-40 \%$ were either untreated or treated with $100 \mu \mathrm{M}$ of $\mathrm{H}_{2} \mathrm{O}_{2}$ for $16 \mathrm{~h}$ while HK1 cells at confluency of 60-70\% were either untreated or treated with $50 \mu \mathrm{M}$ of $\mathrm{H}_{2} \mathrm{O}_{2}$ for $8 \mathrm{~h}$. The cells were then harvested for gDNA extraction and nested IPCR. In the manipulation for nested IPCR, all the samples were subjected to double digestion with Age I and EcoR I (RE3 in Fig. 12).

Fig. 6a shows that numerous IPCR bands of less than $3 \mathrm{~kb}$ which represent the cleaved $A B L$ gene detected in NP69 cells treated with $\mathrm{H}_{2} \mathrm{O}_{2}$ for $16 \mathrm{~h}$ (lanes 9, 10, 12 and 13) and $24 \mathrm{~h}$ (lanes 14-19). Three cleavage bands were identified in the untreated control (lanes 2 and 5). This might be due to spontaneous cell death of untreated cells as detected in our flow cytometric analyses. As shown in the bar chart in Fig. 6b, the cleavage frequencies of the $A B L$ gene detected in NP69 cells treated with $\mathrm{H}_{2} \mathrm{O}_{2}$ for 16 and $24 \mathrm{~h}$ are 1.4-fold $(p=0.004966)$ and 1.8-fold ( $p=0.000009)$ higher than that of the untreated control, respectively.

Similar findings were obtained from the $\mathrm{H}_{2} \mathrm{O}_{2}$ treatment of $\mathrm{HK} 1$ cells. Figure $7 \mathrm{a}$ is a representative gel picture showing the IPCR result obtained from this experiment. The untreated HK1 cells show a few cleavage bands (lanes 


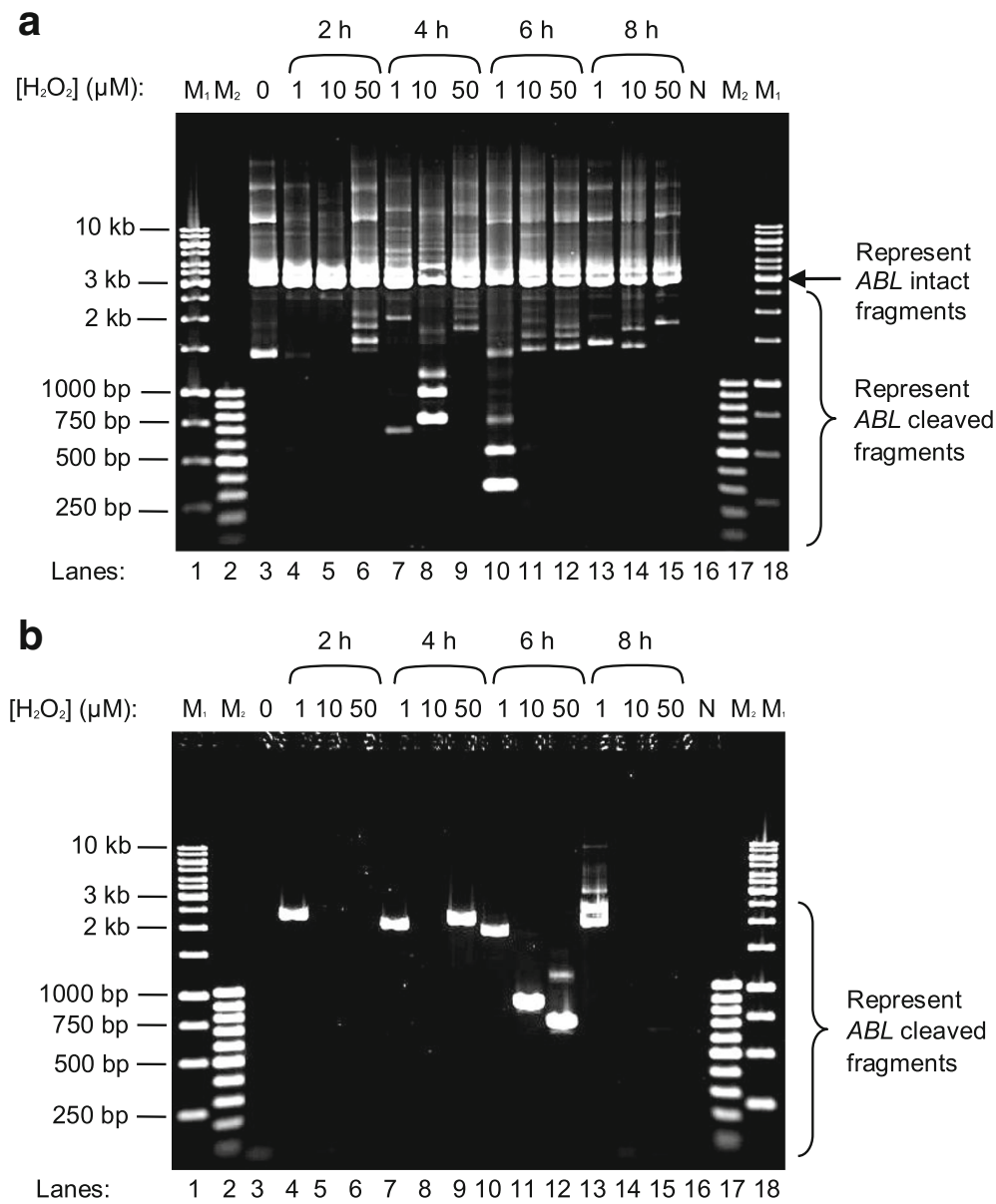

Fig. 5 Nested IPCR detection of DNA breakages within the $A B L$ gene in $\mathrm{H}_{2} \mathrm{O}_{2}$-treated $H K 1$. HK1 cells were seeded in 60-mm culture dishes and were grown to optimal density (60-70\% confluency). The cells were then either untreated (lane 3) or treated with $1 \mu \mathrm{M}$ (lanes 4, 7, 10 and 13), 10 $\mu \mathrm{M}$ (lanes 5, 8, 11 and 14) or $50 \mu \mathrm{M}$ (lanes 6, 9, 12 and 15) of $\mathrm{H}_{2} \mathrm{O}_{2}$ for $2 \mathrm{~h}$ (lanes 4-6), $4 \mathrm{~h}$ (lanes 7-9), $6 \mathrm{~h}$ (lanes 10-12) and $8 \mathrm{~h}$ (lanes 13-15). Genomic DNA was isolated and manipulated for nested IPCR. In the modification for nested IPCR, the DNA samples were either subjected to digestion with Age I (a) or double digestion with Age I and EcoR I (b). The IPCR products were analysed on 1\% agarose gel. Side arrow in panel a indicates the position of the $3 \mathrm{~kb}$ IPCR bands resulting from the amplification of the intact $A B L$ gene. Side brackets in both panels $\mathbf{a}$ and $\mathbf{b}$ indicate the possible IPCR bands from the $A B L$ cleaved fragments. Negative control for PCR was included (lane 16). This IPCR result is representative of 2 repeats with similar results. $M_{1}: 1 \mathrm{~kb}$ DNA ladder. $\mathrm{M}_{2}: 100$ bp DNA ladder

2-7) which most likely due to spontaneous cell death. In contrast, there were numerous cleavage bands identified in the $\mathrm{H}_{2} \mathrm{O}_{2}$-treated sample (lanes 8-13). The chart in Fig. 7b shows that the cleavage frequency of the $A B L$ gene detected in $\mathrm{H}_{2} \mathrm{O}_{2}$-treated $\mathrm{HK} 1$ cells is 1.7-fold higher than that of untreated HK1 cells $(p=0.000197)$.

\section{Sequencing results}

In order to confirm that these fragments were derived from the cleaved $A B L$ gene, some of the cleavage IPCR bands were extracted and sequenced. The sequencing results show that they were all derived from the cleaved $A B L$ gene. Table 2 shows the breakpoints identified within the $A B L$ gene in the $\mathrm{H}_{2} \mathrm{O}_{2}$-treated cells. A map illustrating the positions of chromosome breaks in HK1 and NP69 cells relative to the MAR/SAR sequences within the $A B L$ gene is shown in Fig. 8.

Intriguingly, we detected two shift translocations in $\mathrm{H}_{2} \mathrm{O}_{2}$-treated NP69 cells. Translocation is rarely observed in NPC, compared with deletion and addition. The first shift translocation was identified in NP69 cells exposed to $100 \mu \mathrm{M}$ of $\mathrm{H}_{2} \mathrm{O}_{2}$ for $16 \mathrm{~h}$. As shown in Fig. 9a, the translocated segment was derived from the human lipoma HMGIC fusion partner-like 3 (LHFPL3) gene which is located on chromosome 7. The LHFPL3 gene consisting of three exons is 578,576 bp in length. The description of exons and introns in the LHFPL3 gene is shown in Additional file 4. The translocated segment (228 bp) of the LHFPL3 gene is corresponding to coordinates 108006-108234 [Ensembl:ENSG00000187416]. The breakpoints $(108,006$ and 108,234$)$ of the LHFPL3 

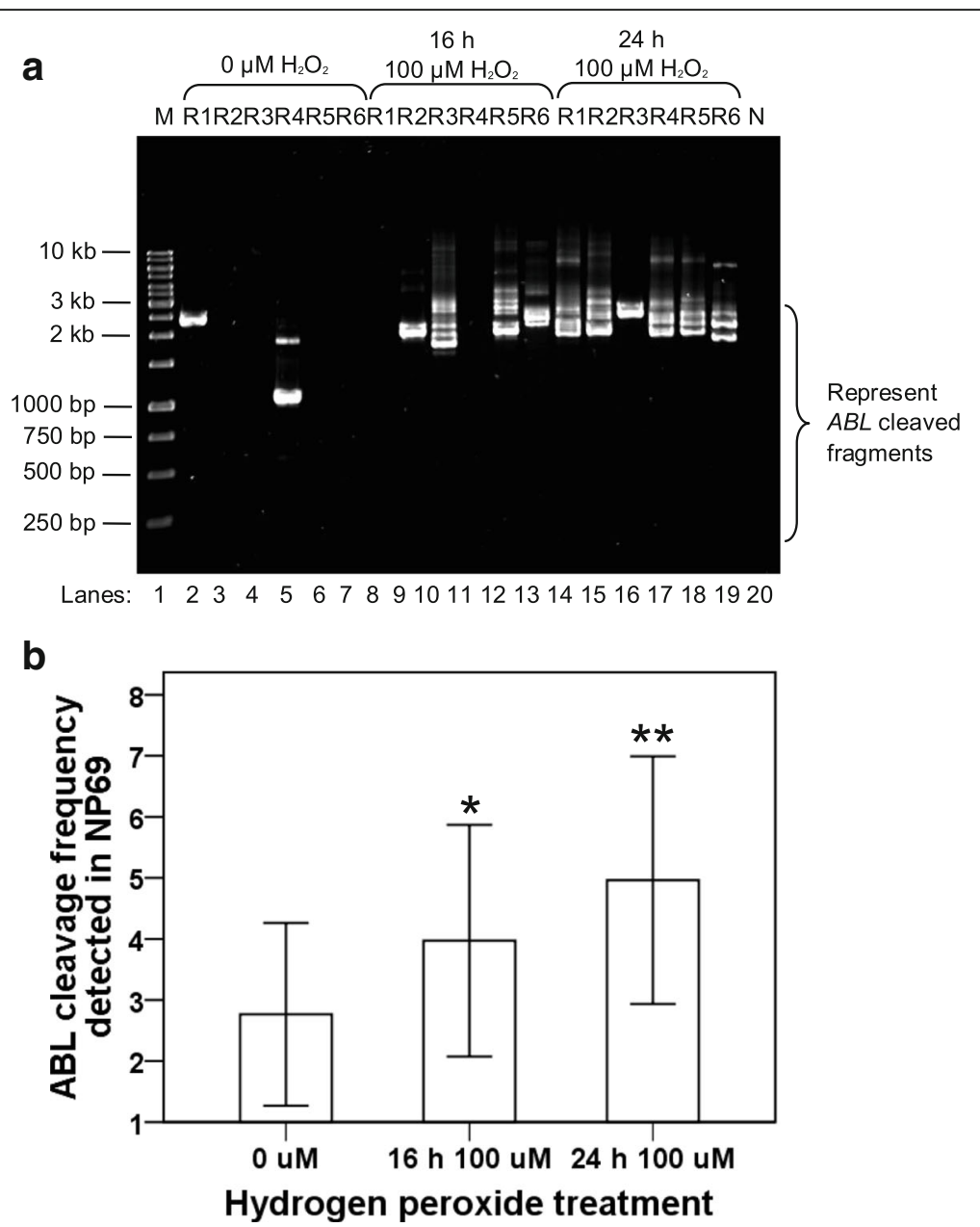

Fig. 6 IPCR analysis of $\mathrm{H}_{2} \mathrm{O}_{2}$-induced chromosome breaks within the $A B L$ gene in NP69 cells. a IPCR result obtained from $\mathrm{H}_{2} \mathrm{O}_{2}$-treated NP69 cells. NP69 cells were either untreated (lanes 2-7) or treated with $100 \mu \mathrm{M}$ of $\mathrm{H}_{2} \mathrm{O}_{2}$ for $16 \mathrm{~h}$ (lanes 8-13) and $24 \mathrm{~h}$ (lanes 14-19). Genomic DNA was isolated and manipulated for nested IPCR. Double digestion with Age I and EcoR I was employed to eliminate competition of the intact fragments in the amplification process. Each cell sample consisted of six replicates (R1-6) in the nested IPCR. The IPCR products were analysed on 1.0\% agarose gel. Side bracket indicates the possible IPCR bands derived from the ABL cleaved chromosome. Negative control for PCR was included (Lane 20). M: 100 bp DNA ladder. b The average number of DNA cleavage detected within the $A B L$ gene. The data was expressed as means and SD of three independent experiments. Each experiment consisted of 1-3 sets of IPCR. Each set of IPCR was performed in 4-7 IPCR replicates for each cell sample. ${ }^{*} p<0.01$, ${ }^{* *} p<0.001$ (Student's $t$ test)

gene were mapped within its first intron. Moreover, region of microhomology (TGCC) was found at the breakpoint junctions. The second shift translocation was identified in NP69 cells exposed to $10 \mu \mathrm{M}$ of $\mathrm{H}_{2} \mathrm{O}_{2}$ for $24 \mathrm{~h}$. The segment translocated to the $A B L$ gene is derived from chromosome 5 . The disabled homologue $2(D A B)$ gene is $1,263,556 \mathrm{bp}$ at the $5^{\prime}$ end of this segment while a gene encoding for hypothetical protein is 22,122 bp at the $3^{\prime}$ end (Fig. 9b).

\section{Discussion}

Oxidative stress increases genomic instability [86] which in turn contributes to carcinogenesis [87, 88]. Excessive production of ROS has been associated with mutation and alteration of gene expression [49]. Most of the aetiological factors of NPC were known to generate ROS. These aetiological factors include exposures to nitrosamines, cigarette smoke, formaldehyde and wood dust. EBV infection as well as chronic inflammation of sinonasal tract $[39,41-43]$.

In addition, formaldehyde and acrolein, a component of cigarette smoke, are reactive aldehydes which may impair the function of DNA, RNA and proteins through adduct formation. It has been suggested that the combined interactions of environmental aldehydes and endogenous aldehydes, which are produced during oxidative stress, may exacerbate the cellular oxidative damage [47].

Although the consistent chromosomal aberrations, such as deletion and addition, have long been identified in $\mathrm{NPC}$, the underlying molecular mechanism requires further investigation. Apoptosis was suggested to participate 


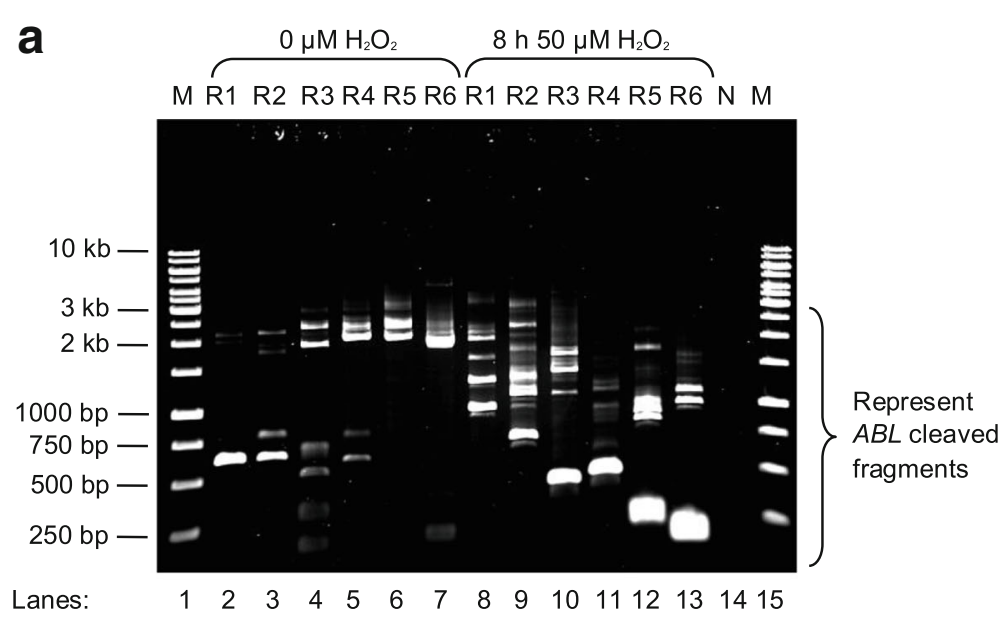

b

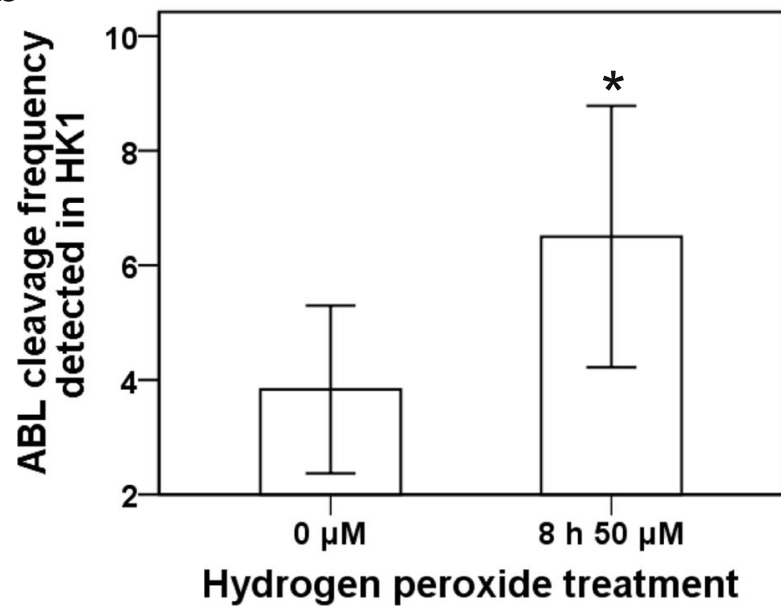

Fig. 7 IPCR analysis of $\mathrm{H}_{2} \mathrm{O}_{2}$-induced chromosome breaks within the $A B L$ gene in $\mathrm{HK} 1$ cells. a IPCR result obtained from $\mathrm{H}_{2} \mathrm{O}_{2}$-treated $\mathrm{HK} 1$ cells. HK1 cells were either untreated (lanes 2-7) or treated with $50 \mu \mathrm{M}$ of $\mathrm{H}_{2} \mathrm{O}_{2}$ for $8 \mathrm{~h}$ (lanes 8-13). Genomic DNA was isolated and manipulated for nested IPCR. In the manipulation for nested IPCR, samples were subjected to double digestion with Age I and EcoR I to eliminate the competition of the intact fragments for amplification process. Each cell sample consisted of six replicates in nested IPCR. The IPCR products were analysed on $1.0 \%$ agarose gel. Side bracket indicates the possible IPCR bands derived from the ABL cleaved chromosome. Negative control for PCR was included (lane 14). M: 100 bp DNA ladder. $\mathbf{b}$ The average number of DNA cleavage detected within the ABL gene. The data was expressed as means and SD of three independent experiments. Each experiment consisted of 1-3 sets of IPCR. Each set of IPCR was performed in 6 IPCR replicates for each cell sample. ${ }^{*} P p<0.001$ (Student's $t$ test)

in the chromosomal translocation process of leukaemia [70]. Given that there is a strong association between the aetiological factors of NPC and oxidative stress, we intended to investigate the role of oxidative stress-induced apoptosis in mediating the chromosome rearrangements of NPC.

We demonstrated that hydrogen peroxide $\left(\mathrm{H}_{2} \mathrm{O}_{2}\right)$, a strong oxidising agent, was able to induce apoptosis in normal nasopharyngeal epithelial cells (NP69) and NPC cells (HK1). Both exposure of PS and disruption of MMP are key events of apoptosis [89, 90]. By using flow cytometric analyses of PS externalisation and MMP loss, we detected significantly higher percentages of apoptosis in $\mathrm{H}_{2} \mathrm{O}_{2}$-treated NP69 and HK1 cells as compared with the untreated controls. As compared with NPC cells (HK1), longer exposure time and higher dosage of $\mathrm{H}_{2} \mathrm{O}_{2}$ were needed to trigger apoptosis in normal nasopharyngeal epithelial cells (NP69). There may be several possibilities that lead to this variation. The intrachromosomal instability in cancer cells is usually higher than that in normal cells [91, 92]. Furthermore, cancer cells may have a defective DNA repair system which is unable to restore the genomic integrity [91]. These factors imply that cancer cells are more susceptible to DNA damage. When apoptosis is triggered by oxidative stress, DNA fragmentation occurs. Cells try to survive apoptosis through DNA repair. Therefore, as compared with normal cells, cancer cells which have a higher intrachromosomal instability or a 
Table 2 The chromosome breaks identified within the $A B L$ gene in cells treated with $\mathrm{H}_{2} \mathrm{O}_{2}$

\begin{tabular}{|c|c|}
\hline Cell line treated with $\mathrm{H}_{2} \mathrm{O}_{2}$ & Breakpoint \\
\hline \multirow[t]{18}{*}{ NP69 } & 129,265 \\
\hline & 129,287 \\
\hline & 129,372 \\
\hline & 129,408 \\
\hline & 129,520 \\
\hline & 129,534 \\
\hline & 129,628 \\
\hline & 129,823 \\
\hline & 130,633 \\
\hline & 130,634 \\
\hline & 130,638 \\
\hline & 130,687 \\
\hline & 130,699 \\
\hline & 130,719 \\
\hline & 130,822 \\
\hline & 130,864 \\
\hline & 131,108 \\
\hline & 131,232 \\
\hline \multirow[t]{9}{*}{ HK1 } & 129,152 \\
\hline & 129,461 \\
\hline & 129,739 \\
\hline & 130,653 \\
\hline & 130,696 \\
\hline & 130,791 \\
\hline & 130,854 \\
\hline & 130,921 \\
\hline & 131,042 \\
\hline
\end{tabular}

The nucleotide positions of the chromosome breaks identified within the $A B L$ gene were mapped according to the $A B L$ sequence retrieved from Ensembl database [Ensembl:ENSG00000097007]

defective DNA repair system are usually more vulnerable to apoptosis.

In our previous report, we identified chromosomal breakages within the AF9 gene in $\mathrm{H}_{2} \mathrm{O}_{2}$-treated NP69 and HK1 cells. In addition, inhibiting caspase- 3 by caspase- 3 inhibitor has abolished the AF9 gene cleavages mediated by $\mathrm{H}_{2} \mathrm{O}_{2}$-induced apoptosis. Given that caspase- 3 is the main activator of CAD-mediated DNA fragmentation in apoptosis, our findings suggested that CAD might be the major player which mediated the chromosomal breakages in $\mathrm{H}_{2} \mathrm{O}_{2}$-induced apoptosis [80]. It has been observed that CAD binds to the nuclear matrix during apoptosis [79]. Due to the fact that MAR/ SAR sequences are the sites where DNA interacts with the nuclear matrix [93], it is likely that CAD cleaves the DNA at MAR/SAR sequences when it associates with nuclear matrix. Intriguingly, our previous report demonstrated that oxidative stress-induced apoptosis caused chromosomal breakages within the AF9 BCR which is bordered by two MAR/SARs [80].

The present study targeted the $A B L$ gene which is located on chromosome $9 \mathrm{q} 34$. This gene was targeted because $9 q 33-34$ is one of the common deletion regions in NPC [23]. The $A B L$ gene is the most common fusion partner gene with the breakpoint cluster region $(B C R)$ gene which is located on chromosome 22q11 [94]. The reciprocal translocation $\mathrm{t}(9 ; 22)(\mathrm{q} 34 ; \mathrm{q} 11)$ in $\mathrm{CML}$ was the first consistent chromosome rearrangement found in malignancy. The $A B L-B C R$ fusion gene was named as the Philadelphia chromosome [95]. This reciprocal translocation was found in approximately 92\% of CML patients. Thus, the $A B L-B C R$ fusion gene is recognised as the cytogenetic hallmark of patients suffering from this disease $[94,96]$. The presence of Philadelphia chromosome was also reported in 20 to $55 \%$ of adults and 2 to $10 \%$ of children with acute lymphoblastic leukaemia (ALL) [97] and rarely (1 to $2 \%$ ) in acute non-lymphoblastic leukaemia (ANLL) [98]. There are three BCRs found within the $A B L$ gene. The first BCR (BCRA) and the second BCR (BCRB) are located in intron $1 \mathrm{~b}$, whereas the third BCR (BCRC) spans through parts of introns $1 \mathrm{~b}$ to 3 . BCRC is the largest $\mathrm{BCR}$ of the $A B L$ gene $[77,99]$.

One biochemically defined MAR/SAR has been previously identified within the BCRC of the $A B L$ gene. This MAR/SAR was designated as SAR1. SAR1 was found within intron 1a [72]. In the present study, we predicted MAR/SAR sites within the $A B L$ gene by using MRS which was proposed to be strongly associated with MAR/SAR [84]. It has been found that the two sequence elements of the MRS exist at a position near the dyad axis of the nucleosome. The wrapping of the DNA around the histone protein complex causes the two sequence elements of the MRS to be physically close together even if they are non-adjacent on the linear DNA. The close proximity between the two sequence elements of the MRS on the positioned nucleosome allows them to generate a protein-binding site in MAR/SAR [84].

The variation in the distance between the two sequence elements suggested a relation of the MRS to nucleosome organisation. In the Drosophila histone cluster, there was a MAR/SAR identified between the histone $\mathrm{H} 1$ and $\mathrm{H} 3$ genes. This MAR/SAR was found to contain a few nucleosomes and two MRSs. It was observed that the position of the two MRSs on their respective nucleosomes is similar. The first MRS, where the two sequence elements are overlapping, is found on the dyad axis of a nucleosome. The second MRS, where the two sequence elements are $145 \mathrm{bp}$ apart, is located near the entry and exit sites of a nucleosome. Although the two sequence elements of the MRS are spatially distant, they are 


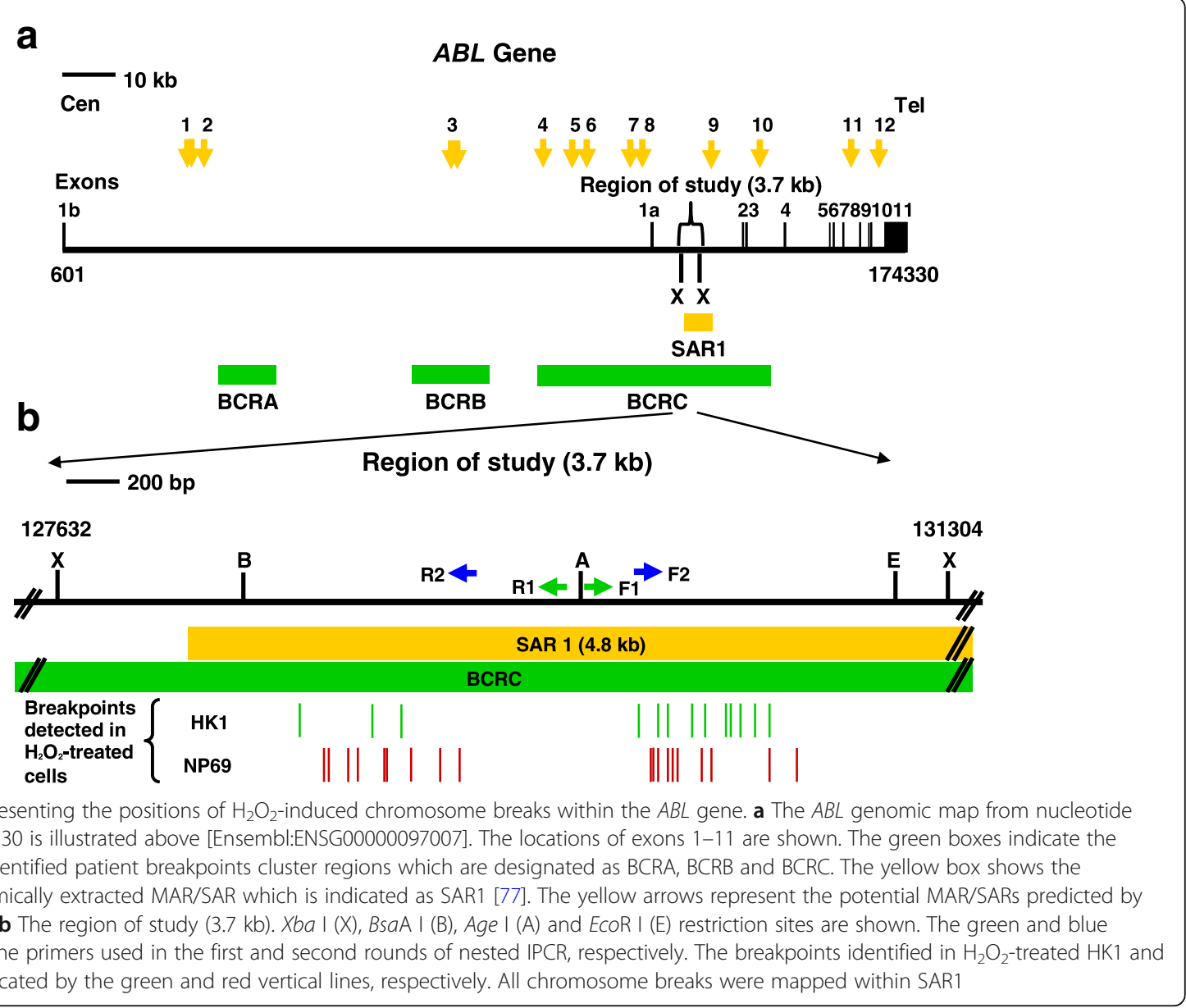

brought close together when the DNA is turned around the histone core [85].

A nucleosome comprises a nucleosome core and a 'linker' DNA. The nucleosome core contains 145-147 bp of DNA wrapped around a core histone octamer. The histone octamer consists of two molecules each of the four core histones, namely, H2A, H2B, H3 and H4 [94]. It has been known that the length of 'linker' DNA ranges from 15 to $100 \mathrm{bp}$, depending on the cell types. The 'linker' DNA connects one nucleosome to the other (reviewed in [95]). The nucleosome repeat length (NRL) refers to the length of nucleosomal DNA (145-147 bp) plus the length of linker DNA (15-100 bp) [94, 95]. Using the micrococcal nuclease assay, the NRL has been reported to range from 160 to $240 \mathrm{bp}[96,97]$.

In the studies by van Drunen et al. (1999), the distance between the two sequence elements of the MRS has been suggested to be within $200 \mathrm{bp}$ [85]. SAR prediction/SAR prediction presently performed in the $A B L$ gene, there was only one MAR/SAR site (MAR/SAR 9 in Table 1) predicted in the experimentally isolated SAR1. The distance between the 8 bp sequence element and the $16 \mathrm{bp}$ sequence element was found to be $248 \mathrm{bp}$.
Given that the NRL may exceed $200 \mathrm{bp}$, for the mapping of MRS in the present study, the maximal distance between the 8 bp sequence element and the 16 bp sequence element was set at $250 \mathrm{bp}$. Besides, it is also possible that the two sequence elements, which are 248 bp apart, are located separately on two adjacent nucleosomes. In the positioned nucleosomes, interaction between two adjacent nucleosomes may happen. Thus, it seems possible that even if the two sequence elements are individually located on two adjacent nucleosomes, the wrapping of DNA around the histone protein complex may still cause them to be physically close together and enable them to generate a protein binding site.

We predicted 12 potential MAR/SAR sites within the $A B L$ gene. One MAR/SAR site was predicted within the biochemically defined SAR1. Interestingly, 10 out of these $12(>80 \%)$ potential MAR/SAR sites are closely associated with the BCRs of the $A B L$ gene (Fig. 1). MAR/ SARs 1 and 2 were predicted next to BCRA. MAR/SAR 3 was found within BCRB. MAR/SARs 4 to 10 were identified within BCRC.

By using IPCR, we identified chromosome breaks in $\mathrm{H}_{2} \mathrm{O}_{2}$-treated NP69 and HK1 cells. The cleavage frequency 
$\longrightarrow$ Direction of forward primer (ABL $130553 \mathrm{~F})$

\begin{tabular}{|c|c|c|c|c|c|}
\hline \multicolumn{6}{|c|}{30} \\
\hline GGGGTTCGTG & GAGTCCTTCA & GGGAGC TCAG & ACTTTTACT & TAGTGG TGGA & 50 \\
\hline AAGGAATAAC & AACCCCAGCC & ATTTTTTGAG & GGCCTGTGC & TGCC TAGGCC & 100 \\
\hline CTCAAAAAAC & ATGTCCATGT & TAGC TGC AAA & C TGCCAGCT & CCCTGCAAAG & 150 \\
\hline CACATCATGA & TCCCAGCATT & GCCCCCGATG & $A C A C T G C D$ T & GACCAATTGT & \\
\hline CСAATAAAAA & TATAATGCAA & ACCAC TTACA & AAAC TT TAA & ATATTCTAGC & \\
\hline AGCC TCATTA & AAAAATATTT & AAGGTGAAAG & TAATATAAC & ATATATTATA & \\
\hline TTTAACCATG & TATCTCCAAA & ATATTATCCT & TTCAACATG & GACACATTCA & 350 \\
\hline TAT TTCAAAT & GC TCAGTAGC & TTC TTGGGGC & TAGGGGC TCD & CATATGGATC & \\
\hline AGTGCAGGTC & TAC TGGGGAA & ATTGCC TGTC & ATTGGGTAGC & CCAGTGCCTC & 450 \\
\hline TGGTGTCAGC & TGACCCCGGA & GTCCATGAAG & ACATGTTAA & AGAAGAGGAA & \\
\hline ATGTGAATGC & TTTCAAACCA & GCCATGGC TG & GCAGCAGAAC & GGGAGGCC TT & \\
\hline TCAGTCTGTT & GCAAATGGCC & TGTGACAATA & AAAATGCC T & TGTGGG TATT & \\
\hline AGCAGGC TGA & C TGTGGACAG & TCTGGATC TG & CGGCCAC TGC & AGGGATTCCT & \\
\hline GGAACCTGTT & GGGAAGGTGT & CCGGCGAGCT & CAC TGTGGTC & TCTGTTAGGA & \\
\hline ATC TGGAGCA & AATCCTATTT & CTTTTGAAAG & CACAGAGAAC & TGTGTTTTTA & \\
\hline CATTATACCT & TTAGGATTTT & GGCCATGGTT & TATATTTCAC & TCAAAACAAA & \\
\hline ATTATGTT & CCCTAGGC TT & TTATATAGGT & TTTCC TGGTO & AGGTTGCATT & \\
\hline TGTTTTTCAA & СTTTACTATC & TGTCATTATT & GC TGC TC T T & TTACAGGTTA & \\
\hline ACAGATTATT & AAAC TGCACT & TTTCAGTACC & TTGTAGC TA & $\triangle G A C A G A C A A$ & \\
\hline GTGCAGGGTG & TTCCACATCT & GAGTCACCCA & GC AGTGC TG & GTGTGAC T & \\
\hline
\end{tabular}

Direction of reverse primer (ABL $129892 \mathrm{R})$

b

$\longrightarrow$ Direction of forward primer (ABL $130553 \mathrm{~F})$

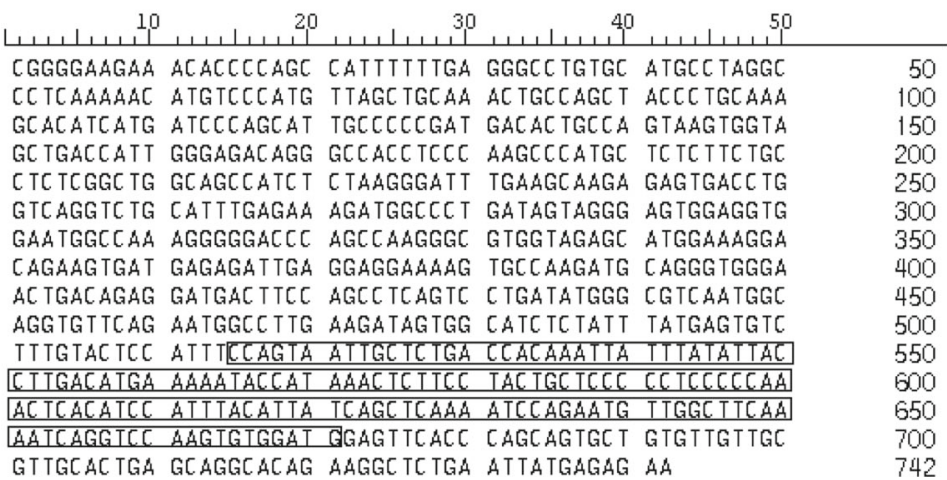

Direction of reverse primer (ABL $129892 \mathrm{R})$

Fig. 9 Shift translocations detected in $\mathrm{H}_{2} \mathrm{O}_{2}$-treated NP69 cells. a Treatment of NP69 with $100 \mu \mathrm{M}$ of $\mathrm{H}_{2} \mathrm{O}_{2}$ for $16 \mathrm{~h}$ resulted in shift translocation. The DNA sequences 1-184 and 413-998 (without the box) represent the sequence derived from the ABL gene. The DNA sequence 185-412 (within the box) represents the sequence derived from the LHFPL3 gene which locates at chromosome 7. Region of microhomology (185-188, TGCC) was found at the breakpoint junctions. The translocated fragment (228 bp) of LHFPL3 gene is corresponding to coordinates 108,006-108,234

[Ensembl:ENSG00000187416]. b Treatment of NP69 with $10 \mu \mathrm{M}$ of $\mathrm{H}_{2} \mathrm{O}_{2}$ for $24 \mathrm{~h}$ resulted in shift translocation. The DNA sequences 1-524 and 672742 (without the box) represent the sequence derived from the ABL gene. The DNA sequence 525-671 (within the box) represents the sequence of the fragment translocated to the $A B L$ gene. This translocated fragment (147 bp) is derived from chromosome 5 . The disabled homologue 2 (DAB) gene is $1,263,556 \mathrm{bp}$ at the $5^{\prime}$ end of this translocated fragment while a gene encoding for a hypothetical protein is $22,122 \mathrm{bp}$ at the $3^{\prime}$ end

of the $A B L$ gene in $\mathrm{H}_{2} \mathrm{O}_{2}$-treated cells was significantly higher than that in the untreated control cells. This is true for both NP69 and HK1 cell lines. These results reaffirm our previous findings which demonstrated that oxidative stress-induced apoptosis resulted in chromosomal breakages in normal nasopharyngeal epithelial and NPC cells [80]. Taken together, our findings are consistent with other studies which discovered that $\mathrm{H}_{2} \mathrm{O}_{2}$ induced apoptotic DNA fragmentation. It has been demonstrated that $\mathrm{H}_{2} \mathrm{O}_{2}$ induced excision of chromosomal DNA loops mediated by topoisomerase II in U937 leukaemic cells [100]. The production of these HMW DNA fragments (50-100 kb loop-sized DNA fragments) is an initial event of apoptosis
[65]. It has also shown that in caspase-3-expressing MCF-7 breast carcinoma cells, $\mathrm{H}_{2} \mathrm{O}_{2}$ activated DNA fragmentation with nucleosomal intervals [101]. The fragmentation of nuclear DNA into nucleosomal DNA ladders is another hallmark of apoptosis [102].

Our sequencing results have confirmed that the IPCR bands were derived from the cleaved $A B L$ gene. All of the breakpoints were mapped within the biochemically defined SAR1 of the $A B L$ gene. SAR1 is located in $\mathrm{BCRC}$, the largest $\mathrm{BCR}$ of the $A B L$ gene [77]. MAR/SAR is thought to be one of the common chromatin structures within BCRs. The BCRs of AF9, MLL and AF4 genes have all been found to associate with MAR/SAR, 
suggesting a role for MAR/SAR in non-homologous recombination (NHR) [76-78]. MAR/SAR sequences were found to possess DNA unwinding properties [103, 104]. These properties allow them to facilitate the entry of protein factors that take part in chromosome condensation, apoptosis, transcription and replication [104, 105]. However, these unwinding properties also cause MAR/SAR sequences to be more prone to DNA breakage $[103,104]$.

In addition, two shift translocations were detected in $\mathrm{H}_{2} \mathrm{O}_{2}$-treated NP69 cells. One of the translocated segments was derived from the LHFPL3 gene which locates at chromosome 7 .

The other translocated segment was derived from chromosome 5. The disabled homologue $2(D A B)$ gene is $1,263,556 \mathrm{bp}$ at the $5^{\prime}$ end of this translocated segment while a gene encoding for hypothetical protein is 22,122 bp at the 3 ' end.

The LHFPL3 gene is one of the family members of LHFP-like genes. This gene family consists of six family members. All of the family members have been implicated in human diseases. Members of this family are transmembrane proteins which play important roles in extracellular matrix formation, differentiation and proliferation. Most of them have been associated with tumours [106]. The first member, LHFP on chromosome 13q12, was identified, for the first time, as a translocation partner of HMGIC gene on chromosome 12q15 in human lipoma with $\mathrm{t}(12 ; 13)(\mathrm{q} 15 ; \mathrm{q} 12)$. Thus, it was annotated as lipoma HMGIC fusion partner (LHFP) gene [107]. The LHFPL1 gene on chromosome Xq23 has been implicated in liver tumour [108]. The LHFPL2 gene on chromosome $5 \mathrm{q} 14.1$ was found to be highly expressed in the novel subgroup of ALL $[109,110]$ and in patients who succumbed fatally to serous epithelial ovarian cancers (SEOC) [111]. The LHFPL4 gene at 3p25.3 was identified as a novel methylation target specific for cervical cancer [112]. Mutation in the LHFPL5 gene (on chromosome 6p21.31) which is also known as tetraspan membrane protein of hair cell stereocilia (TMHS) gene has been found to cause autosomal recessive nonsyndromic deafness [113].

The LHFPL3 gene is located on chromosome 7q22.1. Deletions involving chromosome $7 \mathrm{q} 22$ are commonly observed in uterine leiomyoma (UL). Four distinct deletion intervals have been identified. One of the microdeletions contains the LHFPL3 gene. The single deleted marker in the microdeletion was mapped within the first intron of the LHFPL3 gene. These findings suggested that the LHFPL3 gene is a candidate tumour suppressor gene (TSG) for UL [106]. Deletion of 7q22 has also been associated with leukaemia. A commonly deleted segment of chromosome $7 \mathrm{q} 22$ has been identified in patients with a malignant myeloid disease. The LHFPL3 gene is one of the candidate TSGs residing in this deletion interval [114]. More recently, the alteration of LHFPL3 gene has been suggested to be a hallmark of primary glioblastoma [115].

Intriguingly, region of microhomology (four nucleotides) was found at the breakpoint junctions. This observation suggested that the shift translocation of the LHFPL3 gene might be mediated by NHEJ DNA repair pathway. Based on the analysis of our sequencing data, we illustrated the potential model for the shift translocation of the LHFPL3 gene (Fig. 10). As proposed by Betti and colleagues (2001), the interaction of the NHEJ DNA
LHFPL3 gene

Chromosomal breakage

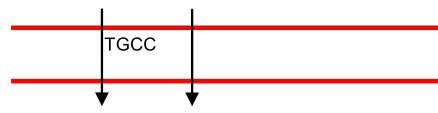

Interstitial deletion
$A B L$ gene

Chromosomal breakage

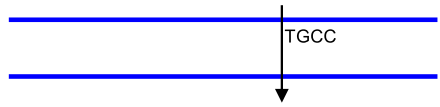

DNA repair through NHEJ pathway

Shift translocation

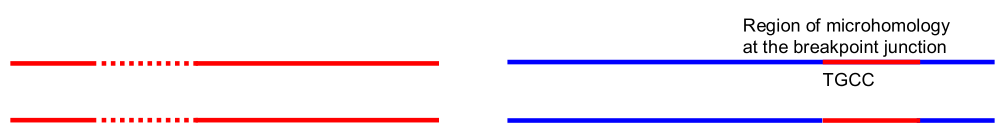

Fig. 10 A potential model for the shift translocation of the LHFPL3 gene. During oxidative stress-induced apoptosis, chromosomal breakages occur within both the LHFPL3 (located at chromosome 7q22) and ABL (located at chromosome 9q34) genes. Following that, interstitial deletion occurs within the LHFPL3 gene. When the cells try to survive apoptosis, DNA repair takes place. By utilising the region of microhomology, TGCC, that was found at the breakpoint junctions of both the LHFPL3 and ABL genes, the two DNA ends were joined. Subsequently, cells that survive apoptosis may carry the $A B L$ gene with the shift translocation of a segment of the LHFPL3 gene 
repair pathway with apoptosis can act as a mechanism leading to translocation in leukaemia. They found that translocation junctions between the $M L L$ gene and the partner DNA contain regions of microhomology consistent with the operation of NHEJ repair process [70]. In addition, it has been found that cells that survive apoptosis may contain rearranged chromosomes that contribute to leukaemogenesis [69]. Taken together, the findings of ours and of others support the notion that the interaction of the NHEJ DNA repair system with oxidative stress-induced apoptosis may be a possible mechanism leading to chromosome rearrangements in NPC.

We previously proposed a potential model for oxidative stress-induced chromosome rearrangements in NPC involving the $A F 9$ gene [80]. Based on the findings of the $A B L$ gene in the present study and additional findings from the literature, we proposed a revised model (Fig. 11). The revision of this model enables us to further elucidate the potential role of oxidative stress-induced apoptosis in mediating chromosome rearrangements in NPC. We propose that oxidative stress plays an essential role in NPC aetiological factors. These include exposure to nitrosamine, wood dust, formaldehyde and cigarette smoke. EBV infection as well as chronic inflammation of sinonasal tract. Oxidative stress-induced apoptosis is initiated by apoptotic signalling. This includes PS externalisation and MMP loss. The apoptotic signalling may in turn result in the activation of the main effector caspase, caspase-3. Caspase-3 cleaves ICAD that contains two caspase- 3 cleavage sites. Subsequently, CAD is being released from its chaperone, ICAD. Chromosomal DNA is cleaved by the activated CAD, presumably at MAR/ SAR sites. Double strand breaks are primarily repaired through NHEJ pathway which is prone to cause erroneous DNA repair. Cells that evade apoptosis may harbour chromosome rearrangements such as translocation, deletion, addition and inversion. Repeated exposure to these aetiological factors that provoke oxidative stress may therefore contribute to tumourigenesis of NPC.

In the present study, we only focused on the SAR region of the $A B L$ gene. It is difficult to draw a solid conclusion on the role of MAR/SAR in defining the positions of the chromosome breakages. Therefore, for the future work, comparison in the cleavage frequency between the $A B L$ SAR region and non-SAR region may be carried out. This may allow a further elucidation of the potential role of MAR/SAR in mediating the chromosome breakages and rearrangements in oxidative stress-induced apoptosis.

\section{Conclusions}

Our findings demonstrated that oxidative stress-induced apoptosis may be a potential mechanism that leads to chromosome rearrangements in NPC. Our results also suggested that NHEJ system is potentially involved in

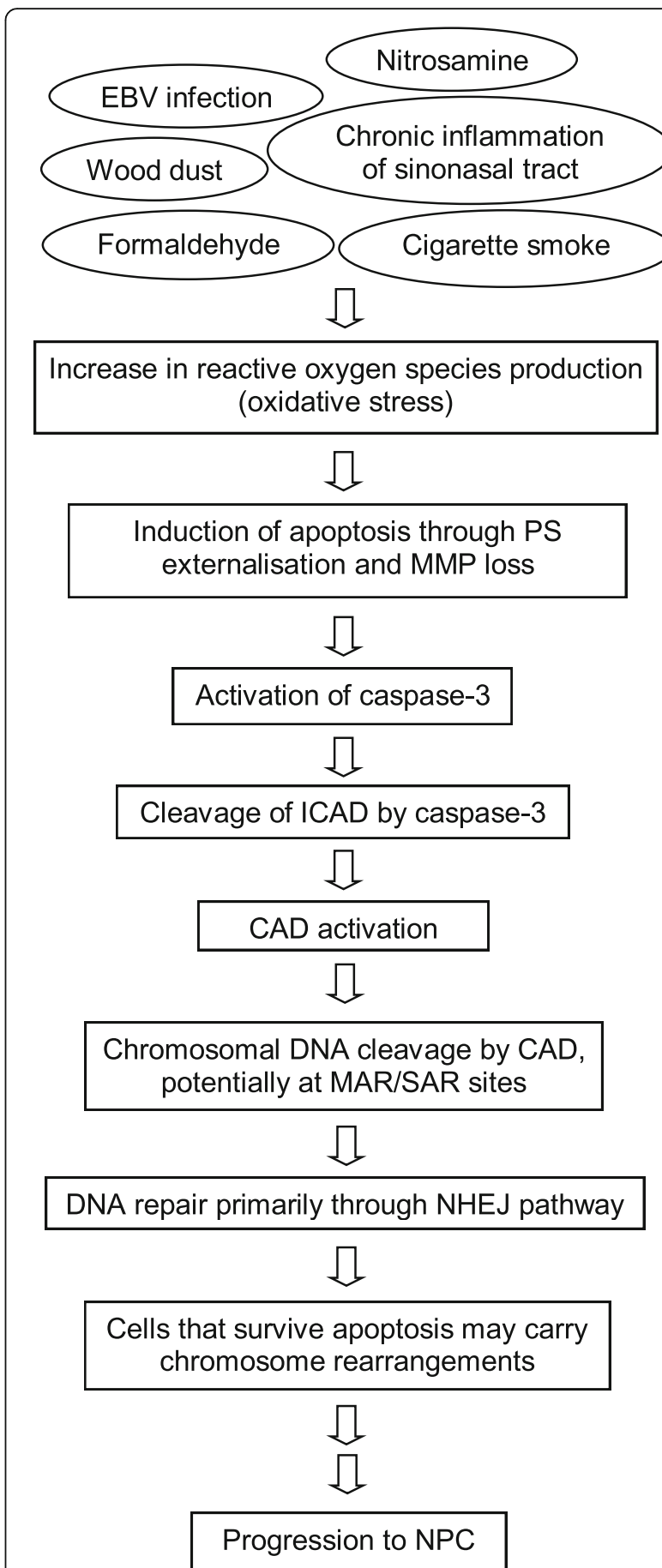

Fig. 11 A revised model for oxidative stress-induced chromosome rearrangement in NPC

DNA repair in cells undergoing oxidative stress-induced apoptosis. The interaction between NHEJ DNA repair system and oxidative stress-induced apoptosis may lead to chromosome rearrangements in surviving cells. A revised model for oxidative stress-induced apoptosis in mediating chromosome rearrangement in NPC is proposed. 


\section{Methods}

\section{Cell lines}

NP69 normal nasopharyngeal epithelial cell line and HK1 NPC cell line were kindly provided by Prof. Tsao Sai Wah (The University of Hong Kong, Hong Kong, China) and Prof. Lo Kwok Wai (The Chinese University of Hong Kong, Hong Kong, China). NP69 is an immortalised nasopharyngeal epithelial cell line which was established by transfection with SV40 large T oncogene. It retains some characteristics of normal nasopharyngeal epithelial cells and is non-tumourigenic. This cell line may provide potential nasopharyngeal epithelial cell model for investigating mechanisms involved in NPC tumourigenesis [116]. HK1 was derived from a Chinese male patient with recurrent squamous NPC 17 1/2 years after radiation therapy [117].

\section{Chemicals}

Hydrogen peroxide $\left(\mathrm{H}_{2} \mathrm{O}_{2}\right)$ was bought from MP Biomedicals, USA. Keratinocyte-SFM medium, RPMI 1640 medium, penicillin, streptomycin, fetal bovine serum and L-glutamine were purchased from GIBCO, Invitrogen, USA. Annexin V-Fluorescein isothiocyanate (FITC) Apoptosis Detection Kit I (BD Pharmingen ${ }^{\mathrm{Tm}}$ ) and Flow Cytometry Mitochondrial Membrane Potential Detection Kit were bought from BD $^{\mathrm{ms}}$ MitoScreen, BectonDickinson Biosciences, USA. Camptothecin (CPT) was purchased from Santa Cruz Biotechnology, CA, USA. Ammonium acetate was bought from Merck, Germany. Chloroform was bought from R\&M Chemicals, UK. Phenol and Sodium dodecyl sulfate (SDS) were procured from Amresco, USA. Isoamyl alchohol was purchased from Fluka, Switzerland. Phusion High-Fidelity DNA Polymerase was procured from Finnzymes, Finland. PCR primers were from First Base Laboratories. QIAquick Gel Extraction Kit and QIAquick Nucleotide Removal Kit were bought from QIAGEN, Germany. DNA Polymerase I Large (Klenow) Fragment, restriction enzymes and T4 DNA Ligase were obtained from New England Biolabs (NEB), USA. dNTP mix was purchased from Promega, USA.

\section{Cell cultures}

NP69 cells were grown in Keratinocyte-SFM medium supplemented with $100 \mu \mathrm{g} / \mathrm{ml}$ streptomycin, $100 \mathrm{U} / \mathrm{ml}$ penicillin, 40-50 $\mathrm{g} / \mathrm{ml}$ Bovine Pituitary Extract (BPE), 4-5 ng/ml recombinant Epidermal Growth Factor (rEGF) and 2\% ( $v / v)$ heat-inactivated fetal bovine serum. HK1 cells were cultured in RPMI 1640 medium supplemented with $100 \mu \mathrm{g} / \mathrm{ml}$ streptomycin, $100 \mathrm{U} / \mathrm{ml}$ penicillin, $2 \mathrm{mM}$ L-glutamine and $10 \%(v / v)$ heat-inactivated fetal bovine serum. Cells were cultured at $37{ }^{\circ} \mathrm{C}$ with $5 \% \mathrm{CO}_{2}$.

\section{In silico prediction of MAR/SAR}

The whole sequence of the $A B L$ gene was retrieved from Ensembl (http://www.ensembl.org/index.html) database [Ensembl:ENSG00000097007]. The location of the experimentally defined MAR/SAR was determined from the previous report [77]. By using DNASTAR software (Lasergene, USA), we predicted the possible MAR/SAR sites within the $A B L$ gene. The prediction of MAR/SAR site was performed by searching MRS which comprises two nucleotide motifs. The first nucleotide motif is an $8 \mathrm{bp}$ degenerate sequence, AATAAYAA, where $\mathrm{Y}=\mathrm{C}$ or $\mathrm{T}$. The second nucleotide motif is a $16 \mathrm{bp}$ degenerate sequence, AWWRTAANNWWGNNNC, where $\mathrm{N}=\mathrm{A}, \mathrm{C}, \mathrm{G}$ or $\mathrm{T} ; \mathrm{R}=\mathrm{A}$ or $\mathrm{G} ; \mathrm{W}=\mathrm{A}$ or $\mathrm{T}$. One mismatch is allowed in the $16 \mathrm{bp}$ degenerate sequence. The $8 \mathrm{bp}$ degenerate sequence has to be exactly matched. The two sequence elements of the MRS should be found within 200 bp apart. The two sequence elements can be present on either Watson or Crick strand and in either order. The two sequence elements may also be overlapping. When there are more than one motif of either 8 or $16 \mathrm{bp}$ found within a distance of $200 \mathrm{bp}$, they are considered as a single MRS. In addition, when there is more than one MRS identified within close proximity, they are regarded as a single potential MAR/SAR site [85].

\section{Apoptosis detection}

Phosphatidylserine (PS) externalisation

NP69 cells $\left(1.5 \times 10^{5}\right)$ were plated in $150-\mathrm{mm}$ culture dishes containing $15 \mathrm{ml}$ of complete media. When NP69 cells reached confluency of $30-40 \%$ on the third day, NP69 cells were either left untreated or treated with $100 \mu \mathrm{M}$ of $\mathrm{H}_{2} \mathrm{O}_{2}$ for 16 and $24 \mathrm{~h}$. HK1 cells $\left(5.5 \times 10^{5}\right)$ were seeded in 150-mm culture dishes containing $15 \mathrm{ml}$ of complete media. When HK1 cells reached confluency of $60-70 \%$ on the fourth day, HK1 cells were incubated with $50 \mu \mathrm{M}$ of $\mathrm{H}_{2} \mathrm{O}_{2}$ for 4 and $8 \mathrm{~h}$. NP69 and HK1 cells treated with camptothecin $(\mathrm{CPT})$ were included as positive controls. After incubation, the cells were collected by using StemPro ACCUTASE Cell Dissociation Reagent. The percentage of apoptotic cells was determined by using Annexin V-FITC Apoptosis Detection Kit I as previously described [80].

\section{Mitochondrial membrane potential (MMP) loss}

NP69 and HK1 cells were treated and collected as described above. The percentage of MMP loss in the harvested cells was determined by using Flow Cytometry Mitochondrial Membrane Potential Detection Kit as previously described [80]. 
IPCR detection of chromosome breaks within the $A B L$ gene Induction of apoptosis in normal nasopharyngeal epithelial and NPC cells with $\mathrm{H}_{2} \mathrm{O}_{2}$

NP69 $\left(2 \times 10^{4}\right)$ and HK1 $\left(8 \times 10^{4}\right)$ cells were seeded in $60-\mathrm{mm}$ culture plates containing $4 \mathrm{ml}$ of complete media. When NP69 cells reached confluency of 30-40\% on the third day, NP69 cells were either left untreated or treated with 10,50 or $100 \mu \mathrm{M}$ for 16 and $24 \mathrm{~h}$. When HK1 cells reached confluency of $60-70 \%$ on the fourth day, HK1 cells were either left untreated or treated with 1,10 or $50 \mu \mathrm{M}$ of $\mathrm{H}_{2} \mathrm{O}_{2}$ for 2, 4, 6 and $8 \mathrm{~h}$.

\section{Genomic DNA extraction}

At the end of the indicated exposure times, the used medium was discarded. The cells were washed once with cold $1 \times$ phosphate-buffered saline (PBS). Genomic DNA extraction was performed as previously described [80].

\section{Manipulation of the extracted gDNA for nested IPCR}

The extracted gDNA was manipulated as described previously [80] with minor modifications. Figure 12 shows the manipulation steps. Digestion of the gDNA was performed at $37{ }^{\circ} \mathrm{C}$ for $16 \mathrm{~h}$ with $100 \mathrm{U}$ of $\mathrm{Xba}$ I (RE1 in Fig. 12). The staggered four base pairs (CTAG) $5^{\prime}$ overhang was produced by $\mathrm{Xba}$ I digestion. The blunt ends were generated by the apoptotic nuclease such as CAD
[118]. After $X b a$ I digestion, both ends of the intact targeted DNA fragment were $\mathrm{Xba}$ I sites with staggered overhangs. As for the cleaved targeted DNA fragment, one end was the blunt end produced by the apoptotic nuclease, and the other end was the staggered overhang generated by $\mathrm{Xba}$ I. To produce blunt-ended fragments, Klenow fill-in was performed with two $\mu \mathrm{g}$ of DNA template, two units of DNA Polymerase I Large (Klenow) Fragment and $33 \mu \mathrm{M}$ of dNTP mix at $25{ }^{\circ} \mathrm{C}$ for $15 \mathrm{~min}$. Cyclisation was then performed with $2000 \mathrm{U}$ of T4 DNA ligase at $16{ }^{\circ} \mathrm{C}$ for $16 \mathrm{~h}$. Ethanol precipitation was carried out with $3 \mathrm{M}$ sodium acetate (NaAc) (one volume), pH 5.2 and ice cold absolute ethanol (2.5 volumes). Seventy percent ethanol was used to wash the DNA pellet. The DNA pellet was then air-dried and dissolved in TE, $\mathrm{pH}$ 8.0. The DNA sample was divided into three. The DNA samples of tubes 1,2 and 3 were subjected to digestion with $10 \mathrm{U}$ of Age I (RE2 in Fig. 12), double digestion with $10 \mathrm{U}$ of each Age I and BsaA I (RE3 in Fig. 12), and double digestion with $10 \mathrm{U}$ of each Age I and EcoR I (RE3 in Fig. 12), respectively. These RE digestions were performed at $37{ }^{\circ} \mathrm{C}$ for $16 \mathrm{~h}$. Digestion with Age I was used to linearise the cyclised DNA. Double digestion with Age I and BsaA I or Age I and $E c o$ R I was used to eliminate competition from the intact fragments during IPCR. The double digestion with

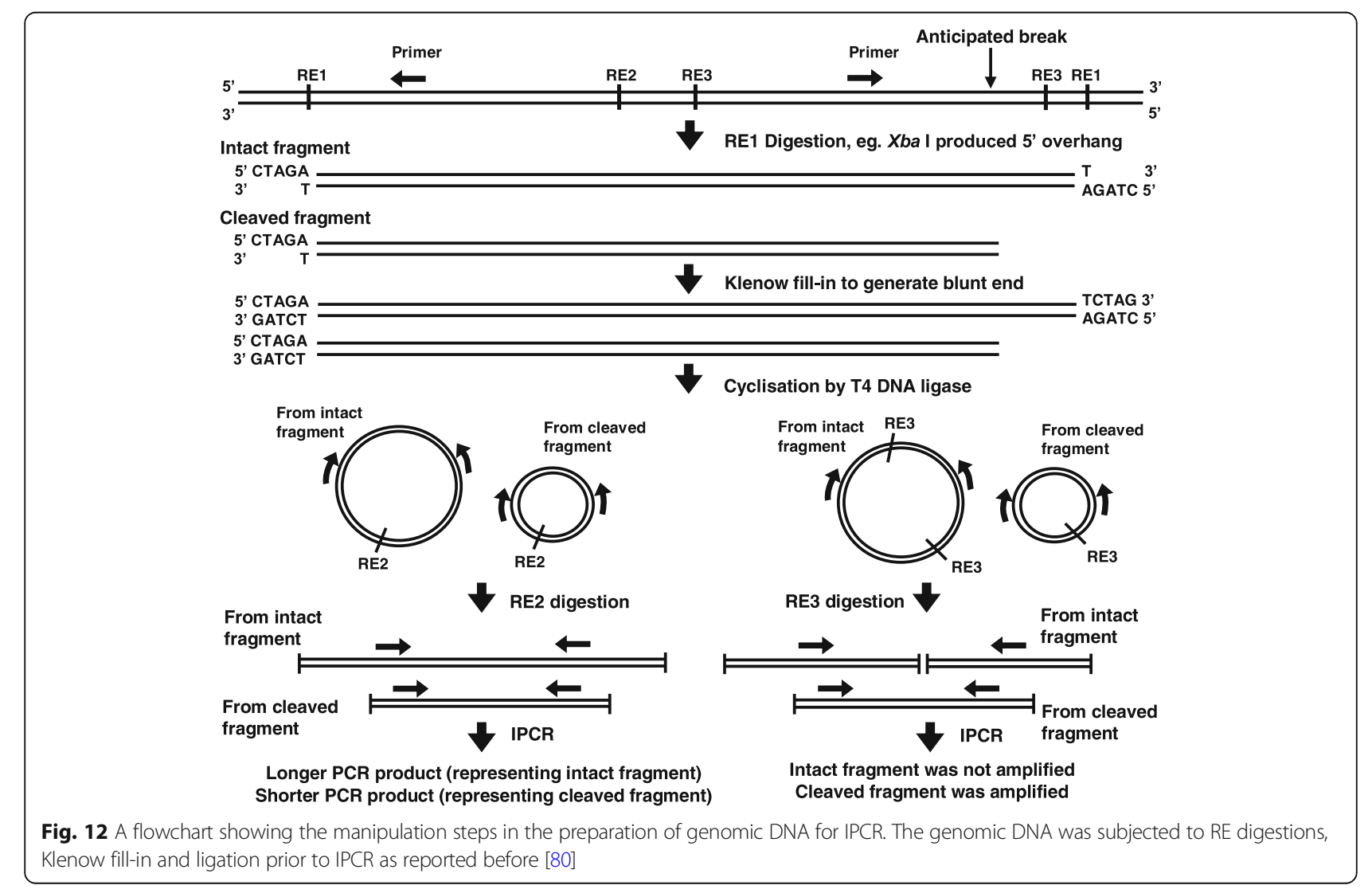


Age I and $B s a \mathrm{~A}$ I enabled the detection of DNA cleavages occurred within the amplified region towards the 3' end. The double digestion with Age I and EcoR I enabled the detection of DNA cleavages occurred within the amplified region towards the $5^{\prime}$ end. According to the manufacturer's protocol, QIAquick Nucleotide Removal Kit (QIAGEN) was used to purify the digested DNA.

\section{Nested IPCR}

The optical density (O.D.) of the purified DNA sample was measured by using an ultraviolet-visible micro-volume spectrophotometer (ND-1000, NanoDrop, USA). Nested IPCR was performed with $1 \times$ of HF buffer (containing $1.5 \mathrm{mM}$ of $\mathrm{MgCl}_{2}$ ), $0.5 \mu \mathrm{M}$ of each reverse primer and forward primer, $200 \mu \mathrm{M}$ of dNTP mix, $0.4 \mathrm{U}$ of Phusion High-Fidelity DNA Polymerase and 200 ng of DNA template. To serve as a negative control, sterile ultrapure water was used to replace the DNA template. Cycle condition used in the first round was: $30 \mathrm{~s}$ of $98{ }^{\circ} \mathrm{C}$ for 1 cycle (initial denaturation), followed by 30 cycles of $98{ }^{\circ} \mathrm{C}$ for $10 \mathrm{~s}$ (denaturation), $64{ }^{\circ} \mathrm{C}$ for $30 \mathrm{~s}$ (annealing), $72{ }^{\circ} \mathrm{C}$ for $55 \mathrm{~s}$ (extension), followed by 1 cycle of $72{ }^{\circ} \mathrm{C}$ for $10 \mathrm{~min}$ (final extension). Similar cycle condition was used in the second round of IPCR, except that the extension time was $50 \mathrm{~s}$. Two microlitres of 5-fold diluted IPCR product of the first round was used as DNA template. The primers used in the first round of IPCR were 5'-GGTACCTGGTGTCT GTCTCTATC-3' (reverse) and 5' -AGAAGGTTTATGGG AGATGG-3' (forward), whereas the primers used in the second round were $5^{\prime}$-TCTCTCATATCTCAGAGCC TTC-3' (reverse) and 5'-CTTCAGGAGCTCAGACTTT TAC-3' (forward). The IPCR assays were done by using a Veriti 96 Well Thermal Cycler (Applied Biosystems, USA).

\section{Agarose gel electrophoresis and DNA sequencing}

The PCR products were analysed on $1 \%$ agarose gel. The agarose gel electrophoresis was performed at $90 \mathrm{~V}$ for $1 \mathrm{~h}$ and $30 \mathrm{~min}$. The agarose gel was briefly stained with ethidium bromide $(0.5 \mu \mathrm{g} / \mathrm{ml})$ and destained with distilled water. This was followed by visualisation of the gel on an ultraviolet (UV) transilluminator (Vilber Lourmat). The gel image was captured and analysed using a gel documentation (gel doc) and image analysis system (Syngene). The IPCR bands representing cleaved DNA fragments of the $A B L$ gene were purified by using QIAquick Gel Extraction Kit (QIAGEN) according to the manufacturer's protocol and sequenced. By blasting the human genome database (Genomic BLAST, https://blast.ncbi.nlm.nih.gov/ Blast.cgi), the sequencing data obtained was annotated. To identify the breakpoints of the cleaved fragments, the sequencing data was analysed and aligned with the published $A B L$ gene sequence [Ensembl:ENSG00000097007] by using Seqman DNASTAR software (Lasergene, USA). The positions of DNA breaks identified were compared with the location of the MAR/SAR sequence isolated experimentally in the previous study [77] and the MRS identified in the present study. A genomic map was constructed to depict the positions of the detected DNA breaks relative to the location of the MAR/SAR.

\section{Quantification of gene cleavage frequency}

In each set of IPCR, four to seven IPCR replicates were prepared per cell sample. Each experiment consisted of one to three sets of IPCR. The number of IPCR bands representing the $A B L$ cleaved fragments was counted. Gene cleavage frequency expresses the average number of $A B L$ cleaved fragments detected in three independent experiments.

\section{Statistical analysis}

Experiments were repeated three to five times. The significance of differences in the gene cleavage frequency detected by nested IPCR was evaluated by Student's $t$ test. Data for IPCR are expressed as mean and standard deviation (SD). Differences were considered statistically significant at $p$ value $<0.05$. All statistical tests are two sided.

\section{Additional files}

Additional file 1: Description of exons and introns in the $A B L$ gene. (PDF $65 \mathrm{~kb}$ )

Additional file 2: Microscopic images of NP69 cells after treatment with $\mathrm{H}_{2} \mathrm{O}_{2}$. (PDF $107 \mathrm{~kb}$ )

Additional file 3: Microscopic images of HK1 cells after treatment with $\mathrm{H}_{2} \mathrm{O}_{2}$. (PDF $150 \mathrm{~kb}$ )

Additional file 4: Description of exons and introns in the LHFPL3 gene. (PDF $56 \mathrm{~kb}$ )

\section{Abbreviations}

ALL: Acute lymphoblastic leukaemia; BCR: Breakpoint cluster region; CAD: Caspase-activated deoxyribonuclease; CML: Chronic myelogenous leukaemia; DAB: Disabled homologue 2; DSB: DNA double-strand breaks; EBV: Epstein-Barr virus; $\mathrm{H}_{2} \mathrm{O}_{2}$ : Hydrogen peroxide; HMW: High-molecularweight; HR: Homologous recombination; ICAD: Inhibitor of caspase-activated deoxyribonuclease; IPCR: Inverse polymerase chain reaction; LHFPL3: Human lipoma HMGIC fusion partner-like 3; MAR/SAR: Matrix association region/ scaffold attachment region; MLL: Mixed lineage leukaemia; MMP: Mitochondrial membrane potential; NHEJ: Non-homologous end joining; NPC: Nasopharyngeal carcinoma; PS: Phosphatidylserine; ROS: Reactive oxygen species; UL: Uterine leiomyoma

\section{Acknowledgements}

We would like to thank the Director-General of Health Malaysia for his permission to publish this article and the Director of Institute for Medical Research Malaysia for her support. We gratefully acknowledge Prof. Tsao Sai Wah (The University of Hong Kong, Hong Kong, China) and Prof. Lo Kwok Wai (The Chinese University of Hong Kong, Hong Kong, China) for providing the normal nasopharyngeal epithelial cell line (NP69) and NPC cell line (HK1). We are especially grateful to Dr. Cornelis M. van Drunen (Academic Medical Center, Amsterdam, The Netherlands) for his precious opinions. We express our gratitude to Universiti Malaysia Sarawak for all infrastructure support. This is also another project by the members of Malaysian Nasopharyngeal Carcinoma Group. 


\section{Funding}

This project was funded by Ministry of Health Malaysia (grant number: 06-065), and the consent for publication has been granted.

\section{Availability of data and materials}

All data generated or analysed during this study are included in this published article.

\section{Authors' contributions}

SNT carried out all the experiments, performed in silico prediction of MAR/ SAR, conducted statistical analyses, constructed genomic maps and wrote the manuscript. SPS conceptualised the main idea of the project, designed the study, interpreted the data, edited the manuscript and supervised the whole project. ASBK contributed to intellectual formulation of the project. All authors read and approved the final manuscript.

\section{Ethics approval and consent to participate}

Not applicable.

\section{Consent for publication}

Not applicable.

\section{Competing interests}

The authors declare that they have no competing interests.

\section{Publisher's Note}

Springer Nature remains neutral with regard to jurisdictional claims in published maps and institutional affiliations.

\section{Author details}

${ }^{1}$ Department of Paraclinical Sciences, Faculty of Medicine and Health Sciences, Universiti Malaysia Sarawak, Sarawak, Malaysia. ${ }^{2}$ Molecular Pathology Unit, Cancer Research Centre, Institute for Medical Research, Kuala Lumpur, Malaysia.

Received: 10 April 2018 Accepted: 28 May 2018

Published online: 18 June 2018

\section{References}

1. Shanmugaratnam K. Histological typing of nasopharyngeal carcinoma. IARC Sci Publ. 1978:20:3-12.

2. Hirayama T. Descriptive and analytical epidemiology of nasopharyngeal cancer. IARC Sci Publ. 1978;20:167-89.

3. Chang ET, Adami HO. The enigmatic epidemiology of nasopharyngeal carcinoma. Cancer Epidemiol Biomark Prev. 2006;15:1765-77.

4. Huang DP, Lo KW. Aetiological factors and pathogenesis. In: van Hasselt CA Gibb AG, editors. Nasopharyngeal carcinoma. Hong Kong: The Chinese University Press: 1999. p. 31-60.

5. Devi BC, Pisani P, Tang TS, Parkin DM. High incidence of nasopharyngeal carcinoma in native people of Sarawak, Borneo Island. Cancer Epidemiol Biomarkers Prev. 2004;13:482-6.

6. Henle W, Henle G. Evidence for an etiologic relation of the Epstein-Barr virus to human malignancies. Laryngoscope. 1977;87:467-73.

7. Dickens P, Srivastava G, Loke SL, Chan CW, Liu YT. Epstein-Barr virus DNA in nasopharyngeal carcinomas from Chinese patients in Hong Kong. J Clin Pathol. 1992:45:396-7.

8. Feng FT, Cui Q, Liu WS, Guo YM, Feng QS, Chen LZ, et al. A single nucleotide polymorphism in the Epstein-Barr virus genome is strongly associated with a high risk of nasopharyngeal carcinoma. Chin J Cancer 2015;34:563-72.

9. Fong LY, Ho JH, Huang DP. Preserved foods as possible cancer hazards: WA rats fed salted fish have mutagenic urine. Int J Cancer. 1979;23:542-6.

10. Armstrong RW, Armstrong MJ, Yu MC, Henderson BE. Salted fish and inhalants as risk factors for nasopharyngeal carcinoma in Malaysian Chinese. Cancer Res. 1983;43:2967-70.

11. Yong SK, Ha TC, Yeo MCR, Gaborieau V, McKay JD, Wee J. Associations of lifestyle and diet with the risk of nasopharyngeal carcinoma in Singapore: a case-control study. Chin J Cancer. 2017:36:3.

12. Armstrong RW, Imrey PB, Lye MS, Armstrong MJ, Yu MC, Sani S. Nasopharyngeal carcinoma in Malaysian Chinese: occupational exposures to particles, formaldehyde and heat. Int J Epidemiol. 2000;29:991-8.
13. Lo KW, Huang DP. Genetic and epigenetic changes in nasopharyngeal carcinoma. Semin Cancer Biol. 2002;12:451-62.

14. Guo XC, Scott K, Liu Y, Dean M, David V, Nelson GW, et al. Genetic factors leading to chronic Epstein-Barr virus infection and nasopharyngeal carcinoma in South East China: study design, methods and feasibility. Hum Genomics. 2006;2:365-75.

15. Chen YJ, Ko JY, Chen PJ, Shu CH, Hsu MT, Tsai SF, et al. Chromosomal aberrations in nasopharyngeal carcinoma analyzed by comparative genomic hybridization. Genes Chromosomes Cancer. 1999;25:169-75.

16. Hui AB, Lo KW, Leung SF, Teo P, Fung MK, To KF, et al. Detection of recurrent chromosomal gains and losses in primary nasopharyngeal carcinoma by comparative genomic hybridisation. Int J Cancer. 1999;82: 498-503.

17. Fang Y, Guan X, Guo Y, Sham J, Deng M, Liang Q, et al. Analysis of genetic alterations in primary nasopharyngeal carcinoma by comparative genomic hybridization. Genes Chromosomes Cancer. 2001;30:254-60.

18. Yan J, Fang Y, Liang Q, Huang Y, Zeng Y. Novel chromosomal alterations detected in primary nasopharyngeal carcinoma by comparative genomic hybridization. Chin Med J. 2001;114:418-21.

19. Li X, Wang E, Zhao YD, Ren JQ, Jin P, Yao KT, et al. Chromosomal imbalances in nasopharyngeal carcinoma: a meta-analysis of comparative genomic hybridization results. J Transl Med. 2006;4:4.

20. Hui AB, Lo KW, Leung SF, Choi PH, Fong Y, Lee JC, et al. Loss of heterozygosity on the long arm of chromosome 11 in nasopharyngeal carcinoma. Cancer Res. 1996;56:3225-9.

21. Mutirangura A, Pornthanakasem W, Sriuranpong V, Supiyaphun P, Voravud $\mathrm{N}$. Loss of heterozygosity on chromosome 14 in nasopharyngeal carcinoma. Int J Cancer. 1998:78:153-6.

22. Lo KW, Teo PM, Hui AB, To KF, Tsang YS, Chan SY, et al. High resolution allelotype of microdissected primary nasopharyngeal carcinoma. Cancer Res. 2000;60:3348-53.

23. Shao JY, Wang HY, Huang XM, Feng QS, Huang P, Feng BJ, et al. Genomewide allelotype analysis of sporadic primary nasopharyngeal carcinoma from southern China. Int J Oncol. 2000:17:1267-75.

24. Huang DP, Lo KW, van Hasselt CA, Woo JK, Choi PH, Leung SF, et al. A region of homozygous deletion on chromosome 9p21-22 in primary nasopharyngeal carcinoma. Cancer Res. 1994;54:4003-6.

25. Lo KW, Huang DP, Lau KM. p16 gene alterations in nasopharyngeal carcinoma. Cancer Res. 1995;55:2039-43.

26. Hu LF, Eiriksdottir G, Lebedeva T, Kholodniouk I, Alimov A, Chen F, et al. Loss of heterozygosity on chromosome arm 3p in nasopharyngeal carcinoma. Genes Chromosomes Cancer. 1996;17:118-26.

27. Hui AB, Or YY, Takano H, Tsang RK, To KF, Guan XY, et al. Array-based comparative genomic hybridization analysis identified cyclin D1 as a target oncogene at 11q13.3 in nasopharyngeal carcinoma. Cancer Res. 2005;65:8125-33.

28. Lo KW, Cheung ST, Leung SF, van Hasselt A, Tsang YS, Mak KF, et al. Hypermethylation of the p16 gene in nasopharyngeal carcinoma. Cancer Res. 1996:56:2721-5

29. Kwong J, Lo KW, To KF, Teo PM, Johnson PJ, Huang DP. Promoter hypermethylation of multiple genes in nasopharyngeal carcinoma. Clin Cancer Res. 2002:8:131-7.

30. Tan SH, Ida H, Goh BC, Hsieh W, Loh M, Ito Y. Analyses of promoter hypermethylation for RUNX3 and other tumor suppressor genes in nasopharyngeal carcinoma. Anticancer Res. 2006;26:4287-92.

31. Yanatatsaneejit $P$, Chalermchai $T$, Kerekhanjanarong V , Shotelersuk $K$, Supiyaphun $P$, Mutirangura A, et al. Promoter hypermethylation of CCNA1, RARRES1, and HRASLS3 in nasopharyngeal carcinoma. Oral Oncol. 2008;44:400-6.

32. Xiao L, Zhou H, Yan J, Liu Y, Song Y. Changes of telomere length in human nasopharyngeal carcinoma. Hua Xi Yi Ke Da Xue Xue Bao. 1999:30:262-4.

33. Wen Z, Xiao JY, Guo MH. Telomere shortening in the pathogenesis of nasopharyngeal carcinoma. Di Yi Jun Yi Da Xue Xue Bao. 2002;22:329-30.

34. Poirier $\mathrm{S}$, Ohshima $H$, de The $G$, Hubert A, Bourgade MC, Bartsch $H$. Volatile nitrosamine levels in common foods from Tunisia, South China and Greenland, high-risk areas for nasopharyngeal carcinoma (NPC). Int J Cancer. 1987;39:293-6

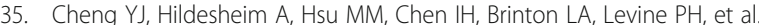
Cigarette smoking, alcohol consumption and risk of nasopharyngeal carcinoma in Taiwan. Cancer Causes Control. 1999:10:201-7.

36. Vaughan TL, Stewart PA, Teschke K, Lynch CF, Swanson GM, Lyon JL, et al. Occupational exposure to formaldehyde and wood dust and nasopharyngeal carcinoma. Occup Environ Med. 2000;57:376-84. 
37. Hung SH, Chen PY, Lin HC, Ting J, Chung SD. Association of rhinosinusitis with nasopharyngeal carcinoma: a population-based study. Laryngoscope. 2014;124:1515-20

38. Tsou YA, Lin CC, Tai CJ, Tsai MH, Tsai TC, Chen CM. Chronic rhinosinusitis and the risk of nasopharyngeal cancer in a Taiwanese health study. Am J Rhinol Allergy. 2014;28:168-72.

39. Carnevali S, Petruzzelli S, Longoni B, Vanacore R, Barale R, Cipollini M, et al. Cigarette smoke extract induces oxidative stress and apoptosis in human lung fibroblasts. Am J Physiol Lung Cell Mol Physiol. 2003;284:L955-63.

40. Uslu C, Taysi S, Bakan N. Lipid peroxidation and antioxidant enzyme activities in experimental maxillary sinusitis. Ann Clin Lab Sci. 2003;33:18-22.

41. van $d$ V, Postma DS, Timens W, ten Hacken NH. Acute effects of cigarette smoke on inflammation and oxidative stress: a review. Thorax. 2004;59:713-21.

42. Kum C, Kiral F, Sekkin S, Seyrek K, Boyacioglu M. Effects of xylene and formaldehyde inhalations on oxidative stress in adult and developing rats livers. Exp Anim. 2007;56:35-42

43. Pylkkanen L, Stockmann-Juvala H, Alenius $H$, Husgafvel-Pursiainen K, Savolainen $\mathrm{K}$. Wood dusts induce the production of reactive oxygen species and caspase-3 activity in human bronchial epithelial cells. Toxicology. 2009;262:265-70.

44. Jones DP. Redefining oxidative stress. Antioxid Redox Signal. 2006;8:1865-79.

45. Halliwell B, Cross CE. Oxygen-derived species: their relation to human disease and environmental stress. Environ Health Perspect. 1994; 102(Suppl 10):5-12.

46. Wiseman $\mathrm{H}$, Halliwell B. Damage to DNA by reactive oxygen and nitrogen species: role in inflammatory disease and progression to cancer. Biochem J. 1996:313(Pt 1):17-29.

47. LoPachin RM, Gavin T. Molecular mechanisms of aldehyde toxicity: a chemical perspective. Chem Res Toxicol. 2014;27:1081-91.

48. Huang YJ, Zhang BB, Ma N, Murata M, Tang AZ, Huang GW. Nitrative and oxidative DNA damage as potential survival biomarkers for nasopharyngeal carcinoma. Med Oncol. 2011;28:377-84.

49. Klaunig JE, Kamendulis LM. The role of oxidative stress in carcinogenesis. Annu Rev Pharmacol Toxicol. 2003;44:239-67.

50. Koul M, Kumar A, Deshidi R, Sharma V, Singh RD, Singh J, et al. Cladosporol A triggers apoptosis sensitivity by ROS-mediated autophagic flux in human breast cancer cells. BMC Cell Biol. 2017;18:26.

51. Sun $Y Y$, Wang $C$, Wang LG, Dai ZB, Yang KB. Arsenic trioxide induces apoptosis and the formation of reactive oxygen species in rat glioma cells. Cellular \& Molecular Biology Letters. 2018;23

52. Park BG, Yoo Cl, Kim HT, Kwon CH, Kim YK. Role of mitogen-activated protein kinases in hydrogen peroxide-induced cell death in osteoblastic cells. Toxicology. 2005;215:115-25

53. Senkoylu A, Yilmaz A, Ergun MA, Ilhan MN, Simsek A, Altun N, et al. Effect of strontium ranelate on hydrogen peroxide-induced apoptosis of CRL-11372 cells. Biochem Genet. 2008;46:197-205.

54. Yoon SO, Kim MM, Park SJ, Kim D, Chung J, Chung AS. Selenite suppresses hydrogen peroxide-induced cell apoptosis through inhibition of ASK1/JNK and activation of PI3-K/Akt pathways. FASEB J. 2002;16:111-3.

55. Ogawa Y, Takahashi T, Kobayashi T, Kariya S, Nishioka A, Mizobuchi H, et al Mechanism of hydrogen peroxide-induced apoptosis of the human osteosarcoma cell line HS-Os-1. Int J Mol Med. 2003;12:459-63.

56. Li J, Huang CY, Zheng RL, Cui KR, Li JF. Hydrogen peroxide induces apoptosis in human hepatoma cells and alters cell redox status. Cell Biol Int. 2000;24:9-23.

57. Kwon D, Choi C, Lee J, Kim KO, Kim JD, Kim SJ, et al. Hydrogen peroxide triggers the expression of Fas/FasL in astrocytoma cell lines and augments apoptosis. J Neuroimmunol. 2001;113:1-9.

58. Stridh $H$, Kimland M, Jones DP, Orrenius S, Hampton MB. Cytochrome C release and caspase activation in hydrogen peroxide- and tributyltininduced apoptosis. FEBS Lett. 1998:429:351-5.

59. Zunino A, Degan P, Vigo T, Abbondandolo A. Hydrogen peroxide: effects on DNA, chromosomes, cell cycle and apoptosis induction in Fanconi's anemia cell lines. Mutagenesis. 2001;16:283-8.

60. Wyllie AH, Kerr JF, Currie AR. Cell death: the significance of apoptosis. Int Rev Cytol. 1980;68:251-306

61. Coleman ML, Sahai EA, Yeo M, Bosch M, Dewar A, Olson MF. Membrane blebbing during apoptosis results from caspase-mediated activation of ROCK I. Nat Cell Biol. 2001;3:339-45.

62. Shimizu T, Maeno E, Okada Y. Prerequisite role of persistent cell shrinkage in apoptosis of human epithelial cells. Sheng Li Xue Bao. 2007;59:512-6.
63. Iguchi K, Hirano K, Hamatake M, Ishida R. Phosphatidylserine induces apoptosis in adherent cells. Apoptosis. 2001;6:263-8.

64. Brown DG, Sun XM, Cohen GM. Dexamethasone-induced apoptosis involves cleavage of DNA to large fragments prior to internucleosomal fragmentation. J Biol Chem. 1993;268:3037-9.

65. Oberhammer F, Wilson JW, Dive C, Morris ID, Hickman JA, Wakeling AE, et al. Apoptotic death in epithelial cells: cleavage of DNA to 300 and/or $50 \mathrm{~kb}$ fragments prior to or in the absence of internucleosomal fragmentation. EMBO J. 1993;12:3679-84.

66. Filipski J, Leblanc J, Youdale T, Sikorska M, Walker PR. Periodicity of DNA folding in higher order chromatin structures. EMBO J. 1990;9:1319-27.

67. Compton MM. A biochemical hallmark of apoptosis: internucleosomal degradation of the genome. Cancer Metastasis Rev. 1992;11:105-19.

68. Bortner CD, Oldenburg NB, Cidlowski JA. The role of DNA fragmentation in apoptosis. Trends Cell Biol. 1995:5:21-6.

69. Vaughan AT, Betti CJ, Villalobos MJ. Surviving apoptosis. Apoptosis. 2002;7:173-7.

70. Betti CJ, Villalobos MJ, Diaz MO, Vaughan AT. Apoptotic triggers initiate translocations within the MLL gene involving the nonhomologous end joining repair system. Cancer Res. 2001;61:4550-5.

71. Paques F, Haber JE. Multiple pathways of recombination induced by double-strand breaks in Saccharomyces cerevisiae. Microbiol Mol Biol Rev. 1999:63:349-404.

72. Lieber MR, Gu J, Lu H, Shimazaki N, Tsai AG. Nonhomologous DNA end joining (NHEJ) and chromosomal translocations in humans. Subcell Biochem. 2010:50:279-96.

73. Weaver DT. What to do at an end: DNA double-strand-break repair. Trends Genet. 1995;11:388-92.

74. Takata M, Sasaki MS, Sonoda E, Morrison C, Hashimoto M, Utsumi H, et al. Homologous recombination and non-homologous end-joining pathways of DNA double-strand break repair have overlapping roles in the maintenance of chromosomal integrity in vertebrate cells. EMBO J. 1998;17:5497-508.

75. Weinstock DM, Richardson CA, Elliott B, Jasin M. Modeling oncogenic translocations: distinct roles for double-strand break repair pathways in translocation formation in mammalian cells. DNA Repair (Amst). 2006;5:1065-74.

76. Strissel PL, Strick R, Tomek RJ, Roe BA, Rowley JD, Zeleznik L. DNA structural properties of AF9 are similar to MLL and could act as recombination hot spots resulting in MLL/AF9 translocations and leukemogenesis. Hum Mol Genet. 2000;9:1671-9.

77. Strick R, Zhang Y, Emmanuel N, Strissel PL. Common chromatin structures at breakpoint cluster regions may lead to chromosomal translocations found in chronic and acute leukemias. Hum Genet. 2006;119:479-95.

78. Broeker PL, Super HG, Thirman MJ, Pomykala H, Yonebayashi Y, Tanabe S, et al. Distribution of 11q23 breakpoints within the MLL breakpoint cluster region in de novo acute leukemia and in treatment-related acute myeloid leukemia: correlation with scaffold attachment regions and topoisomerase ॥ consensus binding sites. Blood. 1996:87:1912-22

79. Lechardeur D, Xu M, Lukacs GL. Contrasting nuclear dynamics of the caspase-activated DNase (CAD) in dividing and apoptotic cells. J Cell Biol. 2004;167:851-62.

80. Tan SN, Sim SP, Khoo AS. Potential role of oxidative stress-induced apoptosis in mediating chromosomal rearrangements in nasopharyngeal carcinoma. Cell Biosci. 2016;6:35.

81. Goff SP, Gilboa E, Witte ON, Baltimore D. Structure of the Abelson murine leukemia virus genome and the homologous cellular gene: studies with cloned viral DNA. Cell. 1980;22:777-85.

82. Wang JY, Ledley F, Goff S, Lee R, Groner Y, Baltimore D. The mouse c-abl locus: molecular cloning and characterization. Cell. 1984;36:349-56.

83. Sawyers CL, McLaughlin J, Goga A, Havlik M, Witte O. The nuclear tyrosine kinase c-Abl negatively regulates cell growth. Cell. 1994;77:121-31.

84. Lugo TG, Pendergast AM, Muller AJ, Witte ON. Tyrosine kinase activity and transformation potency of bcr-abl oncogene products. Science. 1990;247:1079-82.

85. van Drunen CM, Sewalt RG, Oosterling RW, Weisbeek PJ, Smeekens SC, van Driel R. A bipartite sequence element associated with matrix/scaffold attachment regions. Nucleic Acids Res. 1999;27:2924-30.

86. Sallmyr A, Fan J, Rassool FV. Genomic instability in myeloid malignancies: increased reactive oxygen species (ROS), DNA double strand breaks (DSBs) and error-prone repair. Cancer Lett. 2008;270:1-9.

87. Strunnikov AV. One-hit wonders of genomic instability. Cell Div. 2010;5

88. Giam M, Rancati G. Aneuploidy and chromosomal instability in cancer: a jackpot to chaos. Cell Div. 2015;10 
89. Boichuk SV, Minnebaev MM, Mustafin IG. Key role of mitochondria in apoptosis of lymphocytes. Bull Exp Biol Med. 2001;132:1166-8.

90. Fadok VA, Voelker DR, Campbell PA, Cohen JJ, Bratton DL, Henson PM. Exposure of phosphatidylserine on the surface of apoptotic lymphocytes triggers specific recognition and removal by macrophages. J Immunol. 1992;148:2207-16.

91. Anderson GR. Genomic instability in cancer. Curr Sci. 2001;81:501-7.

92. Shen Z. Genomic instability and cancer: an introduction. J Mol Cell Biol. 2011:3:1-3.

93. Cockerill PN, Garrard WT. Chromosomal loop anchorage of the kappa immunoglobulin gene occurs next to the enhancer in a region containing topoisomerase II sites. Cell. 1986;44:273-82.

94. Bartram CR, de Klein A, Hagemeijer A, Grosveld G, Heisterkamp N, Groffen J. Localization of the human C-sis oncogene in Ph1-positive and Ph1-negative chronic myelocytic leukemia by in situ hybridization. Blood. 1984;63:223-5.

95. Nowell PC, Hungerford DA. Chromosome studies on normal and leukemic human leukocytes. J Natl Cancer Inst. 1960;25:85-109.

96. Shtivelman E, Gale RP, Dreazen O, Berrebi A, Zaizov R, Kubonishi I, et al. bcr-abl RNA in patients with chronic myelogenous leukemia. Blood. 1987;69:971-3.

97. Melo JV, Gordon DE, Tuszynski A, Dhut S, Young BD, Goldman JM Expression of the ABL-BCR fusion gene in Philadelphia-positive acute lymphoblastic leukemia. Blood. 1993;81:2488-91.

98. Chen SJ, Chen Z, Font MP, d'Auriol L, Larsen CJ, Berger R. Structural alterations of the $B C R$ and $A B L$ genes in Ph1 positive acute leukemias with rearrangements in the $B C R$ gene first intron: further evidence implicating Alu sequences in the chromosome translocation. Nucleic Acids Res. 1989;17:7631-42.

99. Jiang XY, Trujillo JM, Liang JC. Chromosomal breakpoints within the first intron of the $A B L$ gene are nonrandom in patients with chronic myelogenous leukemia. Blood. 1990;76:597-601.

100. Li TK, Chen AY, Yu C, Mao Y, Wang H, Liu LF. Activation of topoisomerase Il-mediated excision of chromosomal DNA loops during oxidative stress. Genes Dev. 1999:13:1553-60.

101. Kim DK, Cho ES, Um HD. Caspase-dependent and -independent events in apoptosis induced by hydrogen peroxide. Exp Cell Res. 2000;257:82-8.

102. Sakahira $H$, Enari M, Nagata S. Cleavage of CAD inhibitor in CAD activation and DNA degradation during apoptosis. Nature. 1998;391:96-9.

103. Legault J, Tremblay A, Mirault ME. Preferential localization of DNA damage induced by depurination and bleomycin in a plasmid containing a scaffoldassociated region. Biochem Cell Biol. 1997;75:369-75.

104. Bode J, Benham C, Ernst E, Knopp A, Marschalek R, Strick R, et al. Fatal connections: when DNA ends meet on the nuclear matrix. J Cell Biochem Suppl. 2000;Suppl 35:3-22.

105. Gohring F, Schwab BL, Nicotera P, Leist M, Fackelmayer FO. The novel SARbinding domain of scaffold attachment factor A (SAF-A) is a target in apoptotic nuclear breakdown. EMBO J. 1997;16:7361-71.

106. Ptacek T, Song C, Walker CL, Sell SM. Physical mapping of distinct 7q22 deletions in uterine leiomyoma and analysis of a recently annotated $7 q 22$ candidate gene. Cancer Genet Cytogenet. 2007;174:116-20.

107. Petit MM, Schoenmakers EF, Huysmans C, Geurts JM, Mandahl N, Van de Ven WJ. LHFP, a novel translocation partner gene of HMGIC in a lipoma, is a member of a new family of LHFP-like genes. Genomics. 1999:57:438-41.

108. Huang C, Guo J, Liu S, Shan Y, Wu S, Cai Y, et al. Isolation, tissue distribution and prokaryotic expression of a novel human X-linked gene LHFPL1. DNA Seq. 2004;15:299-302.

109. Yeoh EJ, Ross ME, Shurtleff SA, Williams WK, Patel D, Mahfouz R, et al. Classification, subtype discovery, and prediction of outcome in pediatric acute lymphoblastic leukemia by gene expression profiling. Cancer Cell. 2002;1:133-43.

110. Schwaenen C, Wessendorf S, Kestler HA, Dohner H, Lichter P, Bentz M. DNA microarray analysis in malignant lymphomas. Ann Hematol. 2003;82:323-32.

111. Collins Y, Tan DF, Pejovic T, Mor G, Qian F, Rutherford T, et al. Identification of differentially expressed genes in clinically distinct groups of serous ovarian carcinomas using cDNA microarray. Int J Mol Med. 2004;14:43-53.

112. Wang SS, Smiraglia DJ, Wu YZ, Ghosh S, Rader JS, Cho KR, et al. Identification of novel methylation markers in cervical cancer using restriction landmark genomic scanning. Cancer Res. 2008;68:2489-97.

113. Kalay E, Li Y, Uzumcu A, Uyguner O, Collin RW, Caylan R, et al. Mutations in the lipoma HMGIC fusion partner-like 5 (LHFPL5) gene cause autosomal recessive nonsyndromic hearing loss. Hum Mutat. 2006;27:633-9.
114. Curtissa NP, Bonifasa JM, Lauchlea JO, Balkmana JD, Kratza CP, Emerlinga BM, et al. Isolation and analysis of candidate myeloid tumor suppressor genes from a commonly deleted segment of $7 q 22$. Genomics. 2005;85:600-7.

115. Milinkovic V, Bankovic J, Rakic M, Stankovic T, Skender-Gazibara M, Ruzdijic $S$, et al. Identification of novel genetic alterations in samples of malignant glioma patients. PLoS One. 2013;8:e82108.

116. Tsao SW, Wang X, Liu Y, Cheung YC, Feng H, Zheng Z, et al. Establishment of two immortalized nasopharyngeal epithelial cell lines using SV40 large T and HPV16E6/E7 viral oncogenes. Biochim Biophys Acta. 2002;1590:150-8.

117. Huang DP, Ho JH, Poon YF, Chew EC, Saw D, Lui M, et al. Establishment of a cell line (NPC/HK1) from a differentiated squamous carcinoma of the nasopharynx. Int J Cancer. 1980;26:127-32.

118. Widlak P, Garrard WT. Discovery, regulation, and action of the major apoptotic nucleases DFF40/CAD and endonuclease G. J Cell Biochem. 2005;94:1078-87.

\section{Ready to submit your research? Choose BMC and benefit from:}

- fast, convenient online submission

- thorough peer review by experienced researchers in your field

- rapid publication on acceptance

- support for research data, including large and complex data types

- gold Open Access which fosters wider collaboration and increased citations

- maximum visibility for your research: over $100 \mathrm{M}$ website views per year

At BMC, research is always in progress.

Learn more biomedcentral.com/submissions 